\title{
Public Short Selling by Activist Hedge Funds
}

\author{
Ian Appel \\ Carroll School of Management, Boston College \\ ian.appel@bc.edu \\ Jordan Bulka \\ Carroll School of Management, Boston College \\ jordan.bulka@bc.edu \\ Vyacheslav Fos \\ Carroll School of Management, Boston College \\ vyacheslav.fos@bc.edu
}

First Version: March 2018

This Version: November 2018

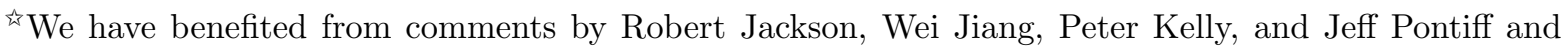
seminar/conference participants at the SEC and Yale Junior Finance Conference. We also thank Sourabh Banthia, Troy Heidenberg, Ryan Leary, Vinh Nguyen, Spencer Olson, Fisher Pressman, and Jonah Schumer for excellent research assistance.
} 


\title{
Public Short Selling by Activist Hedge Funds
}

\begin{abstract}
Using a hand-collected sample of 280 public short selling campaigns, we show that voluntary disclosure of short positions by activist hedge funds has increased significantly in the last decade. Targets of short campaigns experience abnormal returns of approximately $-7 \%$ around the announcement date. Campaigns are also associated with changes in the behavior of other stakeholders (e.g., litigation) that potentially harm targets. Both changes in targets' valuations and stakeholder behavior are not explained by changes in short interest, suggesting that public short campaigns differ from non-public short sales. We consider two economic mechanisms that potentially explain this behavior: information acquisition synergies and the ability to engage in "short investor activism." Finally, we undertake a joint analysis of activists' long and short positions and find that their aggregate effect on the shareholders of targets is indistinguishable from zero. The results highlight the tension between the contribution of activist hedge funds to economic and price efficiency and their effects on targets' shareholders.
\end{abstract}


The last two decades have seen a dramatic increase in the prominence and influence of activist hedge funds. The rise of activists, however, has not been without controversy. While research broadly indicates that, on average, hedge fund activism is followed by improved firm outcomes (Brav, Jiang, Partnoy, and Thomas, 2008; Bebchuk, Brav, and Jiang, 2015), some counter that campaigns often have myopic goals. Martin Lipton, for example, argues that activism promotes "short-termism" and may lead to "...very serious adverse effects on the companies, their long-term shareholders, and the American economy." 1

Although the debate regarding activists centers on their long positions, recent years have seen a new phenomenon: high-profile public short selling campaigns by activist hedge funds. David Einhorn's short of Allied Capital, a publicly traded mezzanine financing firm, provides an illustrative example. In May of 2002, Einhorn announced his short position in Allied at an investment conference, arguing the firm engaged in questionable accounting practices. Allied's stock dropped over $10 \%$ the following day, and by the next month its short interest had increased six-fold. The SEC eventually launched an investigation into Allied that "zero[ed] in on many of the criticisms made by short-sellers." 2

While the finance literature broadly finds that (at least some) short sellers are informed (e.g., Boehmer, Jones, and Zhang, 2008; Engelberg, Reed, and Ringgenberg, 2012; Cohen, Diether, and Malloy, 2007), these investors have historically avoided public disclosure of their positions. One reason for this behavior is that such disclosures may lead to accusations of wrongdoing by managers of firms or other parties. For example, in 2006, Biovail sued SAC Capital for libel, accusing the hedge fund of conspiring to drive down its share price. ${ }^{3}$ Public disclosure of short positions can also invite regulatory scrutiny. For example, both the Manhattan U.S. attorney's office and the FBI investigated potential

\footnotetext{
${ }^{1}$ See: $\quad$ https://corpgov.law.harvard.edu/2013/10/28/empiricism-and-experience-activism-and-shorttermism-the-real-world-of-business/.

${ }^{2}$ See "SEC Is Investigating Allied Capital," The Wall Street Journal (6/24/2004)

${ }^{3}$ See "Judge Dismisses Biovail's Suit Against Hedge Fund," The New York Times (8/20/2009)
} 
market manipulation related to Bill Ackman's short position in Herbalife. ${ }^{4}$ Consistent with the idea that public disclosure of short positions is costly, Jones, Reed, and Waller (2016) and Jank, Roling, and Smajlbegovic (2016) show that mandatory disclosure of short positions leads to a decrease in short selling.

Yet, despite the potentially significant costs, anecdotal evidence suggests activists increasingly disclose their short positions to the public. In this paper, we undertake a comprehensive analysis of voluntary disclosure of short positions by activist hedge funds. We ask four main questions related to this phenomena. First, how common is disclosure of short positions by activists and what are the campaign and target characteristics? Second, what are the effects of short campaigns on firm value and the behavior of stakeholders? Third, why do activist hedge funds engage in this behavior? And finally, what does this behavior imply about the aggregate effects of activists on the shareholders of targets?

To address these questions, we manually construct a database containing information on public short campaigns by activist hedge funds. We identify 280 campaigns by 49 activist hedge funds from 1996-2015. Campaigns are generally disclosed through the media, investment conferences, or letters to investors. Campaigns also feature a wide arrange of allegations, which we group into two types: passive and activist. Passive short campaigns do not aim to affect the underlying cash flows of a target; the goal of such campaigns is rather to convince other investors that the target is overvalued (e.g., due to competitive pressures). In contrast, activist short campaigns specifically seek to change aspects of the target's behavior or its future cash flows. For example, activists often criticize targets' products or business models. If targets' customers adopt activists' views, the demand for targets' products would drop, resulting in lower free cash flows.

We find that the prevalence of public short campaigns has increased significantly in the past decade. Prior to 2008 the average number of public short selling campaigns was

\footnotetext{
${ }^{4}$ See "Prosecutors Interview People Tied to Ackman in Probe of Potential Herbalife Manipulation," The Wall Street Journal 3/12/2015
} 
fewer than 10 per year, but starting in 2008 the average number of campaigns approximately tripled, peaking with 59 in 2015. Approximately one-third of the campaigns are classified as activist and seek to affect the underlying cash flows of the target. We also find that targets of public short campaigns differ from targets of long activism campaigns on important dimensions: short targets tend to be growth firms with strong past performance while long targets tend to be value firms with weak past performance (Brav et al. (2008)).

The announcement of campaigns is associated with negative abnormal returns for targets. Consistent with previous papers that examine disclosure of short positions in other contexts (e.g., Ljungqvist and Qian, 2016; Zhao, 2016), cumulative abnormal returns (CARs) are approximately $-3 \%$ in a $[-10,10]$ window around public disclosure. This negative abnormal performance is not short-lived; CARs decrease to less than $-7 \%$ for the $[-10,100]$ window. For public short selling campaigns classified as activism, the results are even more striking: CARs decrease to less than $-12 \%$ for the $[-10,100]$ window. We obtain similar results for the sample of campaigns announced at investment conferences, suggesting that confounding events (e.g., announcement of negative news) do not drive the findings.

We next examine changes in the behavior of other stakeholders that potentially contribute to the decrease in firm value stemming from public disclosure of short positions. We find that aggregate short interest increases by $10 \%$ following such disclosures. Campaigns are also associated with a sizable increase in media coverage with a negative tone. Finally, disclosures of short positions are followed by an increase in litigation. This result is driven by shareholder lawsuits, fraud/accounting lawsuits, and IP lawsuits, all of which can impose significant costs on firms. Importantly, for both changes in targets' valuations and the behavior of other stakeholders, the results are not driven by changes in aggregate short interest, suggesting the effects of public short campaigns are stronger than those of non-public short sales.

We consider two non-mutually exclusive economic mechanisms that may explain why activist hedge funds voluntarily disclose short positions. First, if activists have the ability 
to decrease the value of targets, public disclosure may facilitate short investor activism. ${ }^{5}$ Similar to long campaigns in which activists seek increase firm value, short activism campaigns seek to influence corporate behavior or future cash flows so as to lower firm value. Indeed, two recent papers by Collin-Dufresne and Fos (2015) and Back, Collin-Dufresne, Fos, Li, and Ljungqvist (2018) develop theoretical models to study activist shareholders who can not only undertake activities to increase the value of long positions, but also take actions to decrease the value of short positions. Approximately one third of our sample consists of short campaigns which activist allegations, indicating that disclosure of some short positions is motivated by activism.

Second, we consider why activists disclose short campaigns with passive allegations. We develop a framework showing that even if activists cannot engage in short activism, the ability to increase the value of long positions incentivizes information acquisition because it can be used for either trading or activism purposes. However, these incentives also make it more likely that activists uncover information that is sufficiently negative to offset the costs associated with disclosure of a short position. If this is the case, the likelihood of voluntary disclosure increases with the activist's ability to increase the value of long positions. Consistent with this prediction, we find that public short selling campaigns are more likely to be undertaken by experienced activists.

Finally, we undertake a joint analysis of both the long and short positions of activist hedge funds to assess their aggregate effect on the existing shareholders of targets. While previous research documents that long campaigns by activists are associated with significant wealth gains for existing shareholders, we find that such gains are offset by negative returns following a short campaign. The aggregate effect of activists on the existing shareholder base of firms they target is indistinguishable from zero. Thus, while there are positive effects of both long activism (e.g., promoting economic and price efficiency) and short activism

\footnotetext{
${ }^{5}$ We use term "investor activism" rather than "shareholder activism" because activist hedge funds do not own shares of their public short selling targets.
} 
campaigns (e.g., reducing fraud), our findings indicate the effect on targets' shareholders may not be positive. This highlights the tension between the contribution of activist hedge funds to economic and price efficiency and their effects on targets' shareholders.

Our findings contribute to multiple strands of literature. First, our paper is related to the literature on hedge fund activism. This literature broadly finds that long campaigns by activists are associated with positive stock price reactions and improved operating performance (e.g., Brav et al., 2008; Becht et al., 2008; Klein and Zur, 2009; Bebchuk et al., 2015; Clifford, 2008). ${ }^{6}$ While this literature focuses on activists buying stakes in firms, our paper shows that these investors increasingly initiate public short selling campaigns. We document the characteristics of such campaigns and show they are associated with large abnormal negative returns. Thus, our findings indicate that the actions of activist hedge funds are not limited to those intended to increase stock prices.

We also contribute to the literature on short selling. Financial economists have long been interested in the relation between short sales and future performance. A number of papers have shown aggregate short interest for a stock is associated with weaker future performance at both the market and individual stock levels (e.g., Seneca (1967); Senchack and Starks (1993); Desai et al. (2002); Rapach et al. (2016)). Previous work has also analyzed alternative measures of aggregate or institutional short selling, including required disclosure in European markets (e.g., Jones et al. (2016)), costs associated with shorting (e.g., Cohen et al. (2007); Jones and Lamont (2002)), and institutional short sale orders (e.g., Boehmer et al. (2008)). A related strand of literature studies the nature of information known by short sellers, including the detection of financial misconduct (Karpoff and Lou (2010)), anticipation of earnings and analyst downgrades (e.g., Christophe et al. (2004); Christophe et al. (2010)), and the ability to process public news releases Engelberg et al.

\footnotetext{
${ }^{6}$ Other papers examine the effect of activists on various outcomes, including innovative activities (Brav et al., 2018), productivity and asset allocation (Brav, Jiang, and Kim, 2015), and takeover offers (Boyson, Gantchev, and Shivdasani (2017); Greenwood and Schor (2009)). See Brav, Jiang, and Kim (2010), Denes, Karpoff, and McWilliams (2017), and Gillan and Starks (2007) for comprehensive reviews of this literature.
} 
(2012)). In contrast to this literature, we examine voluntary disclosures of short positions. While such disclosures have been rare historically, it has become a more common occurrence in recent years. We also provide evidence that public short selling campaigns are associated with chages in the behavior of stakeholders potentially to the benefit of the activist.

Our paper is also related to recent work on public short selling by different market participants. Ljungqvist and Qian (2016) argue that negative research reports issued by small investors help them to overcome limits to arbitrage associated with short selling. Zuckerman (2011) studies the use of public disclosure of short positions by hedge funds as a coordinating mechanism. Finally, Zhao (2016) assembles a database of public short selling campaigns by institutions, research firms, and individual investors and studies target characteristics and announcement returns. In contrast to this earlier work, our paper specifically focuses on public short campaigns by activist hedge funds. A key contribution of our work is to argue that the access to activism technology can explain why activist hedge funds engage in public short selling. In addition, we offer an assessment of the aggregate effects of activists on target shareholders.

\section{Data}

Our sample consists of public short selling campaigns by activist hedge funds between 1996 and 2015. Because US securities laws do not mandate disclosure of short positions, we collect information on campaigns from public sources. To construct the sample, we begin with a list of activist hedge funds from Brav et al. (2010). This list contains hedge funds that have filed a Schedule 13D, indicating an ownership stake of larger than 5\% in a firm and an intent to influence the target. Our focus on activist hedge funds is an important difference between our work and the previous literature that examines voluntary disclosure of short positions by non-activist shareholders. ${ }^{7}$

\footnotetext{
${ }^{7}$ Ljungqvist and Qian (2016) focus on research reports published by arbitrageurs that specialize in short selling, while Zhao (2016) focses on a sample of public short disclosures by various types of investors (e.g., individuals, institutions, research firms, etc.)
} 
We use Factiva to create a database of publicly disclosed short positions by activist hedge funds. Specifically, we conduct searches of the form "Activist Hedge Fund Name" and ("short position" or "short selling"), as well as other variants of these phrases across the newspapers, newswires, blogs, and television transcripts covered by Factiva. In some cases we conduct internet searches to find additional information. For each instance of a public short campaign, we collect the date of the announcement, the revelation method (e.g., investment conference, media interview, release of a white paper, etc.), and the primary allegations made by the activist (e.g., general overvaluation, fraud, threats from competitors, etc.). We match target firms and activist funds to their respective identifiers by searching the CRSP/Compustat merged database and the Thomson Reuters $13 \mathrm{~F}$ database, respectively. The final sample consists of 280 public short selling campaigns by 49 activist hedge funds from 1996-2015.

We merge data from several other sources to our sample. Financial accounting and stock return information are from the Compustat annual files and CRSP daily files, respectively. Short interest and fail-to-deliver data are from Compustat and the SEC, respectively. Institutional ownership data is from Thomson Reuters, and analyst coverage is from IBES. We obtain information on different types of litigation against firms using Audit Analytics. Measures of the quantity and tone of media coverage are from RavenPack News Analytics. All variables are defined in Table A1.

\section{Campaign and Target Characteristics}

In this section, we characterize public short selling campaigns and their targets. Our analysis of campaign characteristics focuses on the prevalence of public short campaigns over time, as well as their allegations and disclosure methods. For our analysis of targets, we document firm characteristics that predict short campaigns and compare them to those of long campaigns undertaken by activist hedge funds. 


\subsection{Campaign Characteristics}

Figure 1 shows the time series distribution of public short selling campaigns. The figure is consistent with anecdotal evidence suggesting that voluntary disclosure of short positions has increased in recent years. Specifically, prior to 2008 the number of public short selling campaigns was fewer than 10 per year. Starting in 2008, however, the number of campaigns increased substantially, averaging 28 per year. While some of campaigns launched in 2007-2008 were in direct response to the financial crisis (e.g., Bill Ackman's campaign against Lehman Brothers), the number of public short selling campaigns by activist hedge funds has remained elevated in the post-crisis period. Indeed, 2015 saw more public short selling campaigns by activist hedge funds than any other year in our sample. Panel B shows the number of activist hedge funds that have launched public short selling campaigns during the sample. The time series pattern is similar to panel A, though the magnitudes are lower indicating that some activists launch multiple campaigns in the same calendar year.

[Insert Figure 1 here]

We next turn attention to the allegations of public short campaigns. For each campaign in our sample, we classify the activists' allegations into six categories: financials/capital structure, industry/competitors, general overvaluation, fraud/accounting, product/business model, and management/insider trading. The classifications are not mutually exclusive, so some campaigns include multiple types of allegations. We further classify the allegations into two broad samples: passive and activist. Passive allegations (financials/capital structure, industry/competitors, and general overvaluation) relate to the valuation of the target. Activist allegations (fraud/accounting, product/business model, and management/insider trading) seek a change inthe firm's practices. The key difference between the samples is that activist allegations seek to directly affect a corporation by infuencing corporate practices or future cash flows. While passive campaigns may lead to 
similar effects (e.g., if there are feedback effects stemming from a lower share price), this is not their primary goal.

Panel A of Table 1 reports the distribution of short campaigns across the types of allegations. Short campaigns with passive allegations that seek to convince other investors that a firm is misvalued constitute approximately two-thirds of our sample. Approximately $13 \%$ of the campaigns in our dataset allege that the target firm has financial or capital structure problems, such as being over-leveraged. Another $24 \%$ of campaigns allege that the target's industry is weak or that the target is at a competitive disadvantage within its industry. About $40 \%$ of the campaigns allege that the target is generally overvalued but provide no further justification for this claim.

The remainder of the sample consists of activist campaigns that seek to directly influence corporate behavior or cash flows. Campaigns that accuse the target of fraud or misleading accounting make up about $13 \%$ of the sample. In these campaigns activists hedge funds demand regulatory action against the firm. Approximately $15 \%$ of campaigns criticize the target's products or business model. These allegation can lead to changes in the demand for targets' products. Finally, close to $5 \%$ of campaigns criticize management or cite insider selling as the reason for the short position. These campaigns can potentially lead to changes in insider trading and even management turnover.

\section{[Insert Table 1 here]}

Panel B reports the distribution of disclosure methods across short campaigns. We classify disclosure methods into four categories: letters to investors, newspapers/television, investment conferences, and white papers/other. Approximately $12 \%$ of the short positions are disclosed in a letter to the fund's investors. The most common form of disclosure, in the newspaper or on television, accounts for about $46 \%$ of the sample. Another $23 \%$ of positions are revealed at investor conferences. The remaining $13 \%$ are either disclosed through white paper or some other form of announcement. 


\subsection{Target Selection}

Table 2 reports characteristics of public short selling targets as well as the difference with matched firms (following the matching methodology in Brav et al. (2008)). The targets differ from the matched sample along a number of dimensions. The starkest difference is in terms of size: on average the market value of equity for targets is close to $\$ 10$ billion larger than matched firms. One potential reason for this finding is that we build our sample based on media coverage of public short selling events. Media, of course, is more likely to cover large companies. Therefore, a large firm is more likely to identified as a public short selling target. We therefore will be using firm size (as measured by market cap) as one of matching criteria in the remaining part of the analysis.

We also find that targets tend to have higher Q, revenue growth, and previous stock returns than matched firms, indicating that they are (on average) growth firms with strong past performance. This is the direct opposite of characteristics of activism campaign targets reported by Brav et al. (2008) (see Table 3), who find such firms tend to be value stocks with weak past performance. However, there are some similarities between the activism and short selling targets of activists hedge funds. Namely, we find evidence that short selling targets tend to have higher institutional ownership, more analyst coverage, and higher leverage, which are also characteristics of activist targets according to Brav et al. (2008). We do not find evidence of differences for book-to-market, ROA, cash flow, cash holdings, or payouts between the public short selling targets and matched firms.

\section{[Insert Table 2 here]}

Table 3 analyzes which variables predict public short selling campaigns using probit model (column 1) and OLS model (columns 2-4). The dependent variable is an indicator variable equal to one if a firm is targeted in a public short selling campaign, and the sample consists of all Compustat firm-year observations from 1996-2015. The evidence presented in this table is broadly consistent with the descriptive statistics in Table 2. In particular, we find robust evidence that the likelihood of targeting is positively associated with firm size 
across the different specifications. Similar to Table 2, we also find targeting is positively related to Q, revenue growth, leverage, and institutional ownership. However, we do not find evidence that targeting is related to analyst coverage.

[Insert Table 3 here]

\section{Shareholder Wealth Effects}

In this section we analyze the effect of public short campaigns on shareholder wealth. Specifically, we analyze the abnormal returns around the announcement of campaigns. We also separately document CARs for both activist and passive campaigns, and we compare abnormal returns to those associated with large changes in short interest.

We first analyze stock price behavior around announcements of public short selling campaigns by activist hedge funds. To conduct this analysis, we calculate the cumulative abnormal returns from the Fama and French three-factor (market, size, and book-tomarket) model from 100 days before the announcement of a public short selling campaign to 100 days after. Figure 2 plots CARs for the [-100, 100] period around the announcement of a public short campaign. Table 4 reports CARs calculated using CAPM, three-factor, and five-factor models for the $[-10,10]$ and $[-10,100]$ periods.

\section{[Insert Figure 2 here]}

Panel A of Figure 2 indicates that the $[-100,100]$ period around the announcement of public short selling campaign by activist hedge funds is characterized by negative stock performance. Prior to the announcement of public short selling campaign, abnormal returns reach $4 \%$, suggesting that the stock could be overvalued. After the announcement, the abnormal return drops to $-7 \%$ and the within few months stabilizes at $-4 \%$ level. Thus, public short selling campaigns lead to a significant change in stock prices, corresponding to about $-8 \%$ CAR. 
Panel A of Figure 2 also provides insights into the abnormal turnover around activist hedge funds' public short campaigns. The dark bars in Figure 2 correspond to abnormal daily turnover. We find negative abnormal turnover during [-100, -20] period and positive abnormal turnover during [-10, 30] period. Abnormal turnover jumps after campaign announcement, indicating that market participants respond to public short selling campaign announcements. Moreover, it validates our empirical setting as it suggests the announcement dates we hand-collect correctly capture the timing of when market participants learn about a campaign. Volume remains elevated for approximately 30 days, and then abnormal turnover is close to zero in the $[30,100]$ period.

Panel B of Figure 2 separately analyzes CARs for campaigns announced at investment conferences and the remainder of the sample (e.g., those announced in newspapers or letters to investors). The light and dark gray lines in this figure show CARs for positions announced and not announced at conferences, respectively. One advantage of analyzing campaigns announced at conferences is that their timing is likely orthogonal to other firmspecific events (e.g., earnings reports) that may have a negative effect on stock prices. In contrast to the rest of the sample, CARs for such campaigns are positive prior to announcement, but fall by a similar magnitude after public disclosure at a conference.

We next compare CARs around short campaigns by activists to large changes in aggregate short interest. The dashed line in Figure 3 shows that large changes in short interest (more than $5 \%$ of shares outstanding) $)^{8}$ take place after the stock experiences positive CARs. Specifically, CARs are about $5 \%$ in the $[-100,-1]$ window. After the stock experiences a large increase in short interest, it realises negative abnormal returns. CARs reduce from $5 \%$ in the $[-100,-1]$ window to $2 \%$ in the $[-100,100]$ window. Thus, large increases in short interest are associated with lower future abnormal returns.

We next consider two types of public short selling campaigns. The grey line in Figure

\footnotetext{
${ }^{8}$ Conditional on experiencing a $5 \%$ of shares outstanding increase in short interest, the average increase in short interest is about $15 \%$ of shares outstanding.
} 
3 corresponds to CARs for campaigns with passive allegations. Overall, pre-event dynamics of CARs for passive public short selling campaigns and large increases in short interest are similar: both groups exhibit 4-5\% CAR. After passive public short selling campaigns are announced, however, stocks experience more negative abnormal returns than after large increases in short interest. Within 100 days CARs for two groups converge. These findings are consistent with passive public short selling campaigns enhancing the flow of negative information into prices.

The dark line in Figure 3 corresponds to CARs for campaigns with activist allegations. Stock price dynamics are very difference for this group of campaigns. Prior to announcement, abnormal returns are small. On the announcement date, target stocks experience sharp negative abnormal returns, reaching $-10 \%$ two weeks after the announcement. Negative abnormal returns continue, leading to approximately $-14 \%$ in the $[-100,100]$ window. The magnitude of this effect is much large than that for passive public short campaigns and for large increases in short interest. This differential suggests the valuation effects of public short campaigns that require an action exceed those of a large change in aggregate short interest.

[Insert Figure 3 here]

Table 4 reports formal statistical tests for the abnormal returns around announcements. In panel A we compare all public short selling campaigns and large increases in short interest. When we consider public short selling campaigns, we find that CARs in the $[-10,10]$ period range from negative $3.3 \%$ to negative $3.5 \%$. Longer-term abnormal returns from $[-10,100]$ range from negative $5.2 \%$ to negative $7.2 \%$, depending on the model used to calculate abnormal returns. Consistently with results in figures, we find that public short selling campaigns experience more negative CARs in the $[-10,10]$ window as well as in the $[-10,100]$ window. For instance, when we use three-factor model, we find that relative to large increases in short interest, CARs for public short selling campaigns are $4.4 \%$ lower 
in the $[-10,10]$ window and $5.7 \%$ lower in the $[-10,100]$ window. These differences are statistically significant at $1 \%$ and $5 \%$ level, accordingly.

[Insert Table 4 here]

In panel B we compare CARs for large increases in short interest and CARs for public short selling campaigns with activist allegations We find that the differences in CARs are significant both economically and statistically. When activist hedge funds actively advocate for real changes (e.g., regulatory enforcement), target firms experience CARs from negative $6.7 \%$ to negative $7.3 \%$ in the $[-10,10]$ period, reaching negative $12 \%$ in the $[-10,100]$ period. These CARs are larger than CARs for large increases in short interest, both statistically and economically. For instance, when we consider three-factor model CARs and [-10,100] period, the difference between CARs is about $10 \%$ and is significant at $5 \%$.

Finally, panel C compares CARs for large increases in short interest and CARs for public short selling campaigns with passive allegations. Consistent with the evidence in Figure 3, the difference in CARs between these two types of events in the $[-10,100]$ window is small economically $(2-3 \%)$ and statistically insignificant. These findings indicate that public short selling campaigns with passive allegations lead to faster flow of information into prices relative to large increases in short interest.

In sum, public disclosure of short positions by activists leads to significantly negative abnormal returns. This finding validates our empirical setting as it suggests market participants we unaware of the campaigns prior to the public disclosure. Moreover, the evidence suggests this effect is not solely driven by a large change in short interest. We also find that when activist hedge funds advocate for real changes, cumulative abnormal returns are more negative. In the next section, we explore whether the negative abnormal returns are (at least partially) the result of a change in behavior by other stakeholders that may have negative effects on firms. 


\section{Actions by Other Stakeholders}

As noted previously, public short selling campaigns may entail significant costs for short sellers. In equilibrium, short sellers will still undertake such campaigns if there are benefits that outweigh these costs. In the previous section, we reported evidence of one such benefit: the announcement of a short campaign is associated with significantly negative abnormal returns in excess of those associated with large changes in short interest. In this section, we turn attention to how the announcement of such campaigns affect the behavior of other stakeholders. We specifically focus on short selling by other market participants, media coverage, and litigation by shareholders and other parties. We hypothesize that public disclosure of short campaigns may lead to changes in the behavior of along these dimensions that may have a negative effect on firm value.

\subsection{Short Interest}

A potential benefit of publicly disclosing a short position (from the perspective of activists) is that it may induce a "bear raid" in which other investors sell the stock (e.g., Goldstein et al., 2013; Khanna and Mathews, 2012). In this section we test whether there are changes in aggregate short selling behavior around the announcement of activist short selling campaigns. To address this question, we estimate the following regression:

$$
y_{i e t}=\alpha \operatorname{Target}_{i t}+\zeta_{e}+\varepsilon_{i e t},
$$

where $y_{i t}$ is aggregate short interest (normalized by shares outstanding) for firm $i$, event $e$, and period $t$, where a period is two weeks. Target ${ }_{i t}$ is a dummy variable that indicates observations after the announcement of a public short selling campaign, and $\zeta_{i}$ are event fixed effects. ${ }^{9}$ The results of this analysis are reported in Table 5.

$$
\text { [Insert Table } 5 \text { here] }
$$

\footnotetext{
${ }^{9}$ In contrast to later tests, we do not include firm-level accounting controls in the regression specification due to the high-frequency nature (bi-weekly) of short interest data.
} 
The positive coefficient for Target $_{i t}$ (both including and excluding event fixed effects in columns 1 and 2, respectively) indicates that total short interest increases in the period following the initiation of a public short selling campaign. The economic magnitude of these effects is sizable, corresponding to over a $10 \%$ increase in short interest for the campaigns in our sample. The coefficient is significant at the $1 \%$ level when we control for time-invariant heterogeneity at the event level.

Figure 4 plots total short interest in the 20 two-week periods around the initiation of a short selling campaign. Panel A shows that there is an upward trend in short interest prior to the public announcement of a campaign. Following the announcement, average short interest continues to increase for approximately 5 periods (i.e., 10 weeks) and then remains relatively stable. This trend potentially reflects the endogenous timing of the announcement of campaigns (e.g., activists may announce campaigns when a company is already performing poorly), but may also be indicative of activists increasing their short position in the stock. Panel B plots short interest for the sample of campaigns revealed at investment conferences. The pre-trend in short interest is less apparent for this sample, and short interest only increased following the public announcement of the campaign.

[Insert Figure 4 here]

Overall, the results are consistent with the idea that public short selling campaigns by activist hedge funds affect short selling by other market participants. Since such short sellers are arguably likely to further push down share prices, this would increase benefits of publicly disclosing short position.

\subsection{Media Coverage}

We next turn attention to the relation between public short selling campaigns by activist hedge funds and media coverage. Previous work finds that media coverage mitigates informational frictions (e.g., Fang and Peress, 2009; Engelberg and Parsons, 2011), and

the tone of such coverage affects returns and volume (e.g., Tetlock, 2007). One potential 
benefit of public disclosure of short positions is that it may influence the likelihood or tone of media coverage of a firm. Such changes may, in turn, further reduce prices and therefore increase the value of activists' short positions.

To study media coverage around public short selling campaigns, we estimate the following OLS regression:

$$
y_{i q}=\alpha \operatorname{Target}_{i q}+X_{i q}^{\prime} \beta+\zeta_{q}+\zeta_{i}+\varepsilon_{i q}
$$

where $y_{i q}$ is outcome variable related to media coverage for firm $i$ and year-quarter $q$, Target $_{i q}$ is a dummy variables that indicates the event quarter and the following three quarters, $X_{i q}$ is a vector of control variables, $\zeta_{q}$ are year-quarter fixed effects, and $\zeta_{i}$ are firm fixed effects.

Table 6 reports results for the tone of media coverage. In this table, we report estimates of regression (2), while considering only strongly negative articles (columns 1 through 4) and strongly positive articles (columns 5 through 8). The sentiment of media coverage as measured by the Event Sentiment Score (ESS) assigned by Ravenpack. We define an article as strongly negative if $\mathrm{ESS}<30$ and as strongly positive is ESS $>70$.

\section{[Insert Table 6 here]}

We find public short selling campaigns are associated with an increase in the number of strongly negative articles.

Coefficients are significant at the $1 \%$ level or lower for each of the specifications. The estimates remain significant after we control for short interest in column 3 and several firm characteristics in column 4, suggesting changes in media coverage are above and beyond of what can be explained by passive short selling. Similarly, columns 5-8 indicate evidence of a corresponding increase in strongly positive articles.

Interpreting the relative economic magnitude of the effect on positive and negative articles is challenging because we use the natural logarithm of one plus the dependent 
variable (due to some firms having zero positive or negative articles). To facilitate the interpretation of the effects, Figure 5 reports the percentage increase relative to the sample mean in the number of articles for each ESS bin. The figure suggests the largest changes in the tone of media coverage are driven by the bins with the most negative tone. While there is a statistically significant increase in coverage for 8 of the 10 bins, the increases are economically largest for negative articles. For instance, three largest percentage increasesranging from $90 \%$ to $110 \%$ - are observed for three most negative ESS bins.

[Insert Figure 5 here]

Overall, the above results indicate that public short selling campaigns by activist hedge funds are associated with a change in media coverage, leading to more negative coverage. This evidence is consistent with the idea that activists may use the media as a platform to disseminate negative information about targets. Indeed, the majority of campaigns $(57.1 \%)$ in our sample are initially revealed via TV or newspaper. Given previous research linking sentiment to stock returns, this is a plausible channel through which public short selling campaigns confer benefits to activists.

\subsection{Lawsuits}

Finally, we consider whether activist short campaigns are associated with changes in the likelihood of litigation. One reason why activists may publicly reveal negative information about a firm is if such an action will lead to lawsuits initiated by regulators, shareholders, or other parties harmed by the target's actions. Such lawsuits may lower firm value due to costs associated with mounting a defense or as part of a settlement or penalty. Indeed, according to one survey of Fortune 200 firms, total litigation costs averaged over $\$ 100$ million per firm in $2008 .{ }^{10}$ Moreover, litigation may also be costly if it

\footnotetext{
${ }^{10}$ See http://www.uscourts.gov/sites/default/files/litigation_cost_survey_of_major_ companies_0.pdf.
} 
leads to a change in corporate behavior (e.g., discontinuing fraudulent practices) as part of a settlement or penalty.

The results of our analysis are reported in Table 7 . The outcome variables are an indicator for litigation in the year following a public short selling campaign and the natural log of one plus the total number of cases in the year following a public short selling campaign in columns 1-4 and 5-8, respectively. ${ }^{11}$ The table reports estimates of the following OLS regression:

$$
y_{i t}=\alpha \text { Target }_{i t}+X_{i t}^{\prime} \beta+\zeta_{t}+\zeta_{i}+\varepsilon_{i t},
$$

where $y_{i t}$ is the litigation-related outcome for firm $i$ in year $t$, Target $_{i t}$ is a dummy variables that indicates year following the event, $X_{i t}$ is a vector of control variables, $\zeta_{t}$ are year fixed effects, and $\zeta_{i}$ are firm fixed effects.

\section{[Insert Table 7 here]}

Our findings indicate public short selling campaigns are associated with an increase in litigation. Specifically, columns 2-4 show that public short selling is associated with an increase in the likelihood of litigation (within firm) of approximately 11-13 percentage points. This effect is economically large relative to the sample mean of $11 \%$. We find similar results for the number of lawsuits faced by firms in columns 5-8. In untabulated results, we break down the specific types of lawsuits and find a positive and statistically significant effect for shareholder lawsuits, fraud/accounting lawsuits, and IP lawsuits. We do not, however, find evidence of a change in antitrust lawsuits or product liability lawsuits.

Overall, the results indicate that public short selling is associated with a significant increase in litigation for targeted firms. These results are consistent with activist hedge funds revealing damaging information through such public short selling campaigns (e.g., fraud) that directly results in the filing of a lawsuit by a damaged party.

\footnotetext{
${ }^{11}$ The types of lawsuits considered include shareholder litigation, fraud or accounting suits (potentially initiated by the SEC or other regulators), IP suits, product liability suits, and antitrust suits.
} 


\section{Discussion of Economic Mechanisms}

In this section, we seek to understand why activist hedge funds engage in public short selling campaigns. We consider two main economic mechanisms that potentially explain our findings. First, public disclosure may facilitate "short investor activism" in which activists attempt to influence corporate decisions or otherwise affect future cash flows. Second, activists have stronger incentives (relative to non-activist investors) to acquire information about firms because they can take actions to increase the value of their long positions. These information acquisition incentives make it more likely that activists learn sufficiently negative information to outweigh the costs associated with disclosure of a short position. We also consider whether public disclosure of short positions is associated with reputational effects or serve as hedges for existing long positions, though we do not find evidence consistent with these explanations.

\subsection{Short Investor Activism}

Activists may disclose short positions because it allows them to influence the actions of a target in ways that reduce firm value (i.e., short investor activism). It is important to note, however, that not all public disclosures of short positions constitute activism. To illustrate this, first consider a long activism campaign. In such a campaign, the activist identifies a company whose future free cash flows can be increased if a certain action is implemented. For example, the activist may believe that replacing a firm's CEO would benefit shareholders. The activist accumulates shares of the target and makes a public announcement about this demand. If market participants agree with the activist, stock prices will increase in anticipation of higher future cash flows. The activist will then engage with the target to influence its behavior.

In both cases, the activist takes an action that is expected to affect a target's future cash flows and trades in the direction of the impact on firm value. Thus, public short campaigns with allegations that aim to change target's practices constitute activism. Indeed, theoretical models by Collin-Dufresne and Fos (2015) and Back, Collin-Dufresne, 
Fos, Li, and Ljungqvist (2018) study activist shareholders who engage not only in long campaigns, but also in short activism campaigns. Our paper provides evidence that is consistent with some public short campaigns being examples of short activism. Specifically, approximately one-third of our sample (i.e., activist short campaigns) aim to influence aspects of corporate behavior or future cash flows. Voluntary disclosure of short positions potentially facilitates such campaigns. Thus, public short campaigns are potentially a result of activists' ability to decrease the value of targets.

However, it is important to note that two-thirds of campaigns in the sample do not have the explicit goal of influencing corporate behavior. Rather, most short campaigns are passive and seek to convince other investors that a stock is misvalued. While such campaigns may still affect corporate decision making (e.g., through feedback effects as in Goldstein et al., 2013), it is public disclosure of these positions is likely not a direct consequence of access to activism technology that lowers firm value. We next explore a potential channel for why activists publicly disclose campaigns with passive allegations.

\subsection{Information Acquisition Synergies}

We next consider whether access to activism technology for long positions increases the expected payoff from the disclosure of short positions. We formally develop a theoretical framework describing this mechanism in Appendix B. In our framework, an investor can acquire information about a firm. If the firm is undervalued, the investor can purchase the stock and choose whether or not to initiate a shareholder activism campaign. If the firm is overvalued, the investor can short the stock and choose whether or not to publicly disclose the position. Assuming disclosure is costly, the investor will take this action only if his private information about the firm is sufficiently negative, such that the expected benefits of disclosure (e.g., due to actions by other stakeholders) exceed its costs.

We assume that the activist has access to activism technology that allows him to increase the value of long positions. This technology incentivizes information collection because positive information can be used for either trading or activism purposes. That 
is, because the activist can increase firm value if he learns that the firm is a good target for shareholder activism, this creates an incentive to learn information. However, this investment in information acquisition also makes it more likely that the investor uncovers information that is sufficiently negative to justify the public disclosure of short positions. This potential mechanism suggests that short campaigns are more likely to be undertaken by skilled or experienced activists (i.e., those with access to effective activism technology) because they will have relatively stronger incentives to acquire information.

We find evidence that the characteristics of activists are consistent with this explanation. First, in Table 8 we examine whether activist hedge funds that undertake short campaigns differ from those who do not in terms of their previous experience with shareholder activism. In this table, we sort activist hedge funds into quartiles based on their number of previous long campaigns. For this analysis, we use the updated sample of activism campaigns from Brav et al. (2008), which consists primarily of 13D filings by activist hedge funds. There is a wide range of experience among the activists in our sample; those in the first quartile have undertaken just one activism campaign, while those in the fourth have undertaken 17 on average (median=12). For each quartile we report the average number of public short selling campaigns in column 4. Activist hedge funds in quartiles 1 and 2 (i.e., those with the least activism experience) initiated 0.036 and 0.348 public short selling campaigns, respectively. However, those in quartiles 3 and 4 (with the most activism experience) initiated 1.222 and 1.034 public short selling campaigns, respectively. Thus, consistent with the information acquisition mechanism, our findings indicate public short campaigns are more likely to be undertaken by more experienced activists.

[Insert Table 8 here]

In Table A2 we examine whether there are differences in the tactics used for long campaigns by activist hedge funds with public short selling experience. Our findings indicate that activist hedge funds that undertake short campaigns tend to be more hostile 
than those that do not. ${ }^{12}$ Specifically, the likelihood of initial hostility is 4.8 percentage points higher for activist hedge funds with public short selling experience, while the likelihood of hostility at any point during activism campaign is 4.4 percentage points higher. In addition, there is evidence that such activist hedge funds have more ambitious goals; the likelihood of seeking a sale is 5.7 percentage points higher and the likelihood of seeking a change in business strategy is 4.4 percentage points higher for activist hedge funds with public short selling experience. To the extent that the use of hostile tactics and ambitious goals are correlated with activist skill, the differences in tactics are also consistent with the information acquisition mechanism.

\subsection{Alternative Mechanisms}

We next consider alternative explanations for why activist investors voluntarily disclose short positions. First, successful campaigns may improve the reputation of activists and lead to higher returns for subsequent long activism campaigns. For example, successful public short selling campaigns may lead to higher abnormal returns for subsequent activism campaigns if it leads to more support from long-term investors (Appel et al., 2018). To test this idea, we regress long campaign CARs on CARs for previous short campaigns. Specifically, we run the following regression:

$$
C A R_{f i}^{\text {long }}=\alpha C A R_{f i}^{\text {short }}+X_{i}^{\prime} \delta+\zeta_{t}+\zeta_{f}+\varepsilon_{i}
$$

where $C A R_{i}^{\text {long }}$ is the abnormal return for long campaign $i$ for activist hedge fund $f$, $C A R_{f}^{\text {short }}$ is the abnormal return for public short selling campaigns for fund $f$ in the preceding 12 months, $X_{i}$ is a vector of control variables, $\zeta_{t}$ are year fixed effects, and $\zeta_{f}$ are activist hedge fund fixed effects. The results are reported in the Appendix Table A3. We find little evidence that CARs for public short campaigns are related to subsequent CARs

\footnotetext{
${ }^{12}$ Brav et al. (2008) define hostile campaigns that includes actions such as threatening/initiating a proxy fight, suing the company, or intending to take control of the company.
} 
for long activism campaigns. If anything, the coefficients are positive across the different specifications, though only statistically different from zero in two instances. Overall, our results suggest that there are not strong reputation effects associated with public short selling campaigns by activists.

Second, short positions may serve as hedges for existing long positions. Specifically, activists may undertake such campaigns as part of a pair-trade with an existing long position. To conduct this analysis, we test whether public short campaigns are associated with the weights of competitors in activists' portfolios. Specifically, we estimate the following regression:

$$
\text { Target }_{i t}=\alpha \text { CompetitorPortfolioWeight }_{i t}+X_{i t}^{\prime} \beta+\zeta_{t}+\zeta_{i}+\varepsilon_{i t},
$$

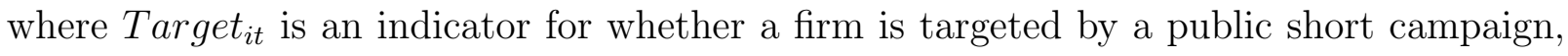
Competitor PortfolioWeight ${ }_{i t}$ is the activists' portfolio weight in competitors, $X_{i t}$ is a vector of control variables, $\zeta_{t}$ are year fixed effects, and $\zeta_{i}$ are firm fixed effects. We define competitor portfolio weights (and score weighted portfolio weights) based on classifications by Hoberg and Phillips (2010) and Hoberg and Phillips (2016). Table A4 in the Appendix reports the results. The results indicate hedging is not a primary motivation for public short campaigns.

\section{Discussion and Implications}

Our analysis indicates that short campaigns, particularly those with activist allegations, are associated with negative CARs. In contrast, the previous literature shows that long campaigns by activists are associated with positive gains for shareholders (e.g., Brav et al. (2008)). One interpretation of these findings is that activists are skilled in identifying misvalued stocks (both over- and under-valued) and potentially taking actions to correct mispricings. However, the effect of activists on the existing shareholders of targets is unclear. When an activist launches a long campaign, the holdings of existing shareholders 
increase in value on average; when it launches a short campaign, the holdings of existing shareholders decrease in value on average. In this section we analyze the overall effect of activist hedge funds on shareholder wealth.

The results of our analysis are illustrated by Figure 6. The light grey line shows the cumulative value-weighted abnormal returns for long activism campaigns. Similar to Brav et al. (2008), we find that long campaigns are associated with abnormal returns of approximately $4 \%$ using a three-factor model. ${ }^{13}$ In untabulated results, we find this effect is highly statistically significant. The dark grey line shows the cumulative valueweighted abnormal returns for public short selling campaigns. The abnormal returns reach approximately $-7 \%$ and, as noted in Table 4 , are also statistically significant. The black line in Figure 6 shows the cumulative value-weighted abnormal returns for all campaigns (i.e., both long activism and public short selling campaigns) undertaken by activist hedge funds. The value-weighted CARs for the aggregate sample are negative, though statistically noisy. Thus, the overall effect of activist hedge funds on target shareholders' wealth is indistinguishable from zero.

[Insert Figure 6 here]

Overall, this finding raises questions related to the aggregate effect of activists on financial markets. Traditional metrics that are aligned with interests of existing shareholders (e.g., abnormal returns) fail to detect a positive effect of activists, thus highlighting the tension between the contribution of activist hedge funds to economic and price efficiency and their effects on targets' shareholders. The main reason for this tension is that enhancing economic efficiency (e.g., by reducing fraud) can go against interests of existing shareholders.

\footnotetext{
${ }^{13}$ Note that we use value-weighted CARs, which leads to slightly lower average abnormal returns.
} 


\section{Conclusion}

Short sellers have been cast as villains throughout history; they have served as scapegoats for the collapse of the Dutch East India Company, the stock market crashes of 1929 and 1987, and the recent financial crisis. ${ }^{14}$ Even today, disclosure of short positions is often met with hostility by managers, regulators, and the public at large. Despite these costs, voluntary disclosure of short positions by activist hedge funds has become increasingly common in recent years.

In this paper, we study the emergence of public short selling campaigns by activists. While such campaigns were rare prior to 2008, there have been an average of nearly 30 per year since. Short campaigns target growth firms and are associated with long-term negative abnormal returns of nearly $-7 \%$. The abnormal returns are driven by activist campaigns that specifically seek to influence corporate behavior or future cash flows as opposed to passive campaigns that seek to convince other investors that a firm is misvalued. Moreover, short campaigns are associated with changes in the behavior of other stakeholders, including an increase in overall short interest, negative media coverage, and litigation.

We highlight two economic mechanisms that potentially explain the findings. First, because some campaigns explicitly aim to change firms' cash flows, voluntary disclosure may also facilitate short activism. Second, the ability of activists to increase the value of long positions incentivizes information acquisition, making it more likely that they uncover sufficiently negative information to justify public disclosure of a short position. Consistent with this mechanism, we find that short campaigns tend to be undertaken by more experienced activists..

Finally, we jointly analyze activists' long and short positions to assess their aggregate effect on target shareholders. We find the negative abnormal returns for short campaigns offset the positive returns of long campaigns, and the overall cumulative abnormal return for shareholders of activists' targets is indistinguishable from zero.

\footnotetext{
${ }^{14}$ See "Short sellers have been the villain for 400 years," Reuters 9/26/2008
} 
Overall, while public disclosure of short positions is costly, our findings indicate that the benefits of disclosure outweigh the costs for some activists. This suggests that the costs and benefits of disclosure potentially vary across investor types. Understanding these incentives may play an important role in informing the policy debate regarding disclosure rules for short sales. 


\section{References}

Appel, I., Gormley, T., Keim, D., 2018. Standing on the shoulders of giants: The effect of passive owner on activism. Review of Financial Studies, forthcoming.

Back, K., Collin-Dufresne, P., Fos, V., Li, T., Ljungqvist, A., 2018. Activism, strategic trading, and liquidity. Econometrica 86, 1431-1643.

Bebchuk, L. A., Brav, A., Jiang, W., 2015. The long-term effects of hedge funds activism. Columbia Law Review 115, 1085-1155.

Becht, M., Franks, J., Mayer, C., Rossi, S., 2008. Returns to shareholder activism: Evidence from a clinical study of the hermes uk focus fund. The Review of Financial Studies 22 (8), 3093-3129.

Boehmer, E., Jones, C. M., Zhang, X., 2008. Which shorts are informed? The Journal of Finance 63 (2), 491-527.

Boyson, N. M., Gantchev, N., Shivdasani, A., 2017. Activism mergers. Journal of Financial Economics 126 (1), 54-73.

Brav, A., Jiang, W., Kim, H., 2010. Hedge fund activism: A review. Foundations and Trends in Finance 4 (3), 1-66.

Brav, A., Jiang, W., Kim, H., 2015. The real effects of hedge fund activism: Productivity, asset allocation, and labor outcomes. The Review of Financial Studies 28 (10), 27232769 .

Brav, A., Jiang, W., Ma, S., Tian, X., 2018. How does hedge fund activism reshape corporate innovation? Journal of Financial Economics 130 (2), 237-264.

Brav, A., Jiang, W., Partnoy, F., Thomas, R., 2008. Hedge fund activism, corporate governance, and firm performance. The Journal of Finance 63 (4), 1729-1775.

Christophe, S. E., Ferri, M. G., Angel, J. J., 2004. Short-selling prior to earnings announcements. The Journal of Finance 59 (4), 1845-1876.

Christophe, S. E., Ferri, M. G., Hsieh, J., 2010. Informed trading before analyst downgrades: Evidence from short sellers. Journal of Financial Economics 95 (1), 85106.

Clifford, C. P., 2008. Value creation or destruction? Hedge funds as shareholder activists. Journal of Corporate Finance 14 (4), 323-336.

Cohen, L., Diether, K. B., Malloy, C. J., 2007. Supply and demand shifts in the shorting market. The Journal of Finance 62 (5), 2061-2096.

Collin-Dufresne, P., Fos, V., 2015. Shareholder activism, informed trading, and stock prices, working paper. 
Denes, M. R., Karpoff, J. M., McWilliams, V. B., 2017. Thirty years of shareholder activism: A survey of empirical research. Journal of Corporate Finance 44, 405-424.

Desai, H., Ramesh, K., Thiagarajan, S. R., Balachandran, B. V., 2002. An investigation of the informational role of short interest in the nasdaq market. The Journal of Finance 57 (5), 2263-2287.

Engelberg, J., Parsons, C., 2011. The causal impact of media in financial markets. The Journal of Finance 66 (1), 67-97.

Engelberg, J. E., Reed, A. V., Ringgenberg, M. C., 2012. How are shorts informed? Short sellers, news, and information processing. Journal of Financial Economics 105 (2), 260278.

Fang, L., Peress, J., 2009. Media coverage and the cross-section of stock returns. The Journal of Finance 64 (5), 2023-2052.

Gillan, S. L., Starks, L. T., 2007. The evolution of shareholder activism in the United States. Journal of Applied Corporate Finance 19 (1), 55-73.

Goldstein, I., Ozdenoren, E., Yuan, K., 2013. Trading frenzies and their impact on real investment. Journal of Financial Economics 109 (2), 566-582.

Greenwood, R., Schor, M., 2009. Investor activism and takeovers. Journal of Financial Economics 92 (3), 362-375.

Hoberg, G., Phillips, G., 2010. Product market synergies and competition in mergers and acquisitions: A text-based analysis. The Review of Financial Studies 23 (10), 3773-3811.

Hoberg, G., Phillips, G., 2016. Text-based network industries and endogenous product differentiation. Journal of Political Economy 124 (5), 1423-1465.

Jank, S., Roling, C., Smajlbegovic, E., October 2016. Flying under the radar: The effects of short-sale disclosure rules on investor behavior and stock prices, working paper.

Jones, C. M., Lamont, O. A., 2002. Short-sale constraints and stock returns. Journal of Financial Economics 66 (2-3), 207-239.

Jones, C. M., Reed, A. V., Waller, W., 2016. Revealing shorts an examination of large short position disclosures. The Review of Financial Studies 29 (12), 3278-3320.

Karpoff, J. M., Lou, X., 2010. Short sellers and financial misconduct. The Journal of Finance 65 (5), 1879-1913.

Khanna, N., Mathews, R. D., 2012. Doing battle with short sellers: The conflicted role of blockholders in bear raids. Journal of Financial Economics 106 (2), 229 - 246.

Klein, A., Zur, E., 2009. Entrepreneurial shareholder activism: Hedge funds and other private investors. The Journal of Finance 64 (1), 187-229. 
Kyle, A. S., 1985. Continuous auctions and insider trading. Econometrica 53, 1315-1335.

Ljungqvist, A., Qian, W., 2016. How constraining are limits to arbitrage? The Review of Financial Studies 29 (8), 1975-2028.

Rapach, D. E., Ringgenberg, M. C., Zhou, G., 2016. Short interest and aggregate stock returns. Journal of Financial Economics 121 (1), 46-65.

Senchack, A. J., Starks, L. T., 1993. Short-sale restrictions and market reaction to shortinterest announcements. Journal of Financial and Quantitative Analysis 28 (2), 177-194.

Seneca, J. J., 1967. Short interest: bearish or bullish? The Journal of Finance 22 (1), $67-70$.

Tetlock, P., 2007. Giving content to investor sentiment: The role of media in the stock market. The Journal of Finance 62 (3), 1139-1168.

Zhao, W., 2016. Activist short-selling, working paper.

Zuckerman, R., 2011. Synchronized arbitrage and the value of public announcements, working paper. 


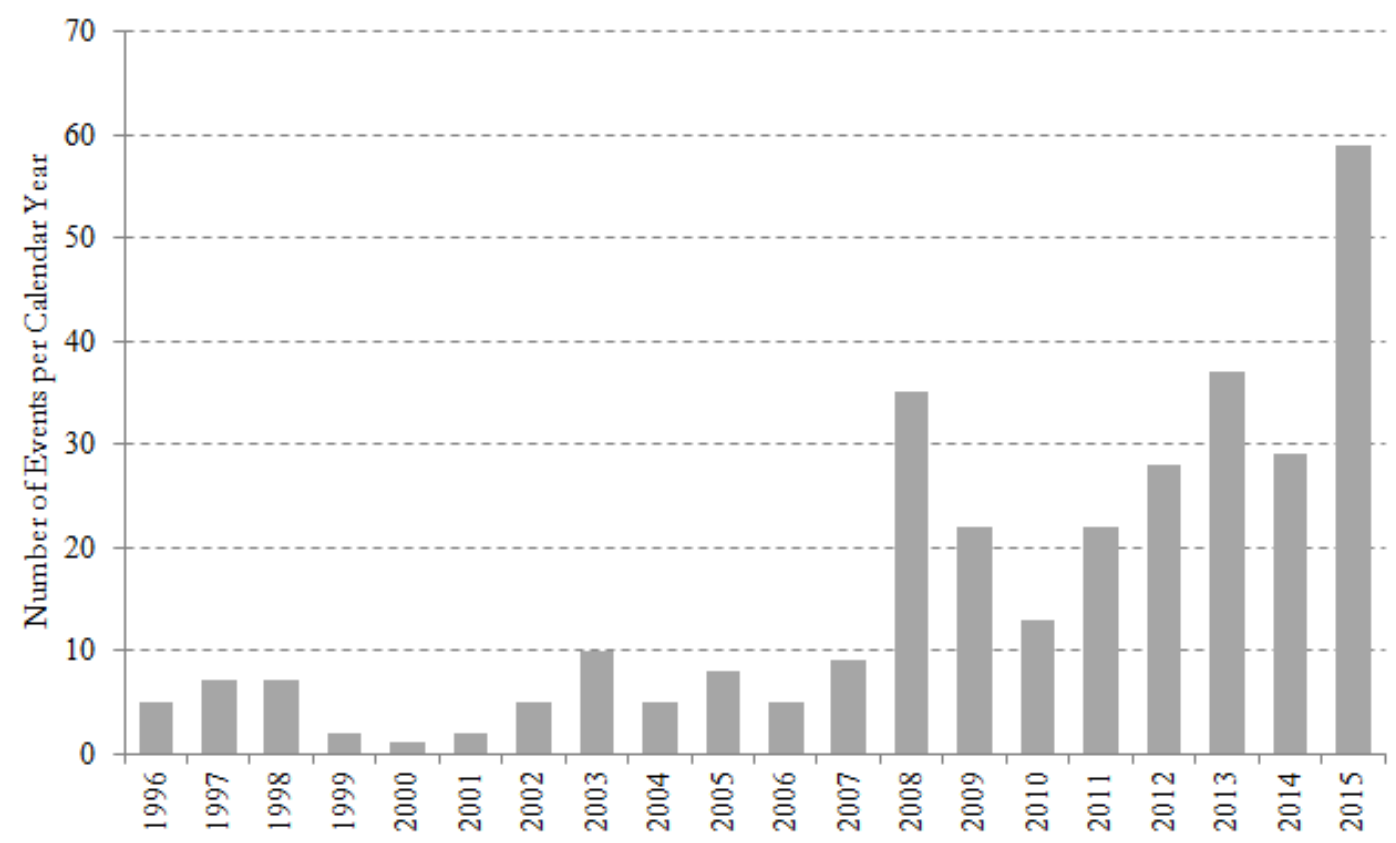

(a) Time Series Distribution of Campaigns

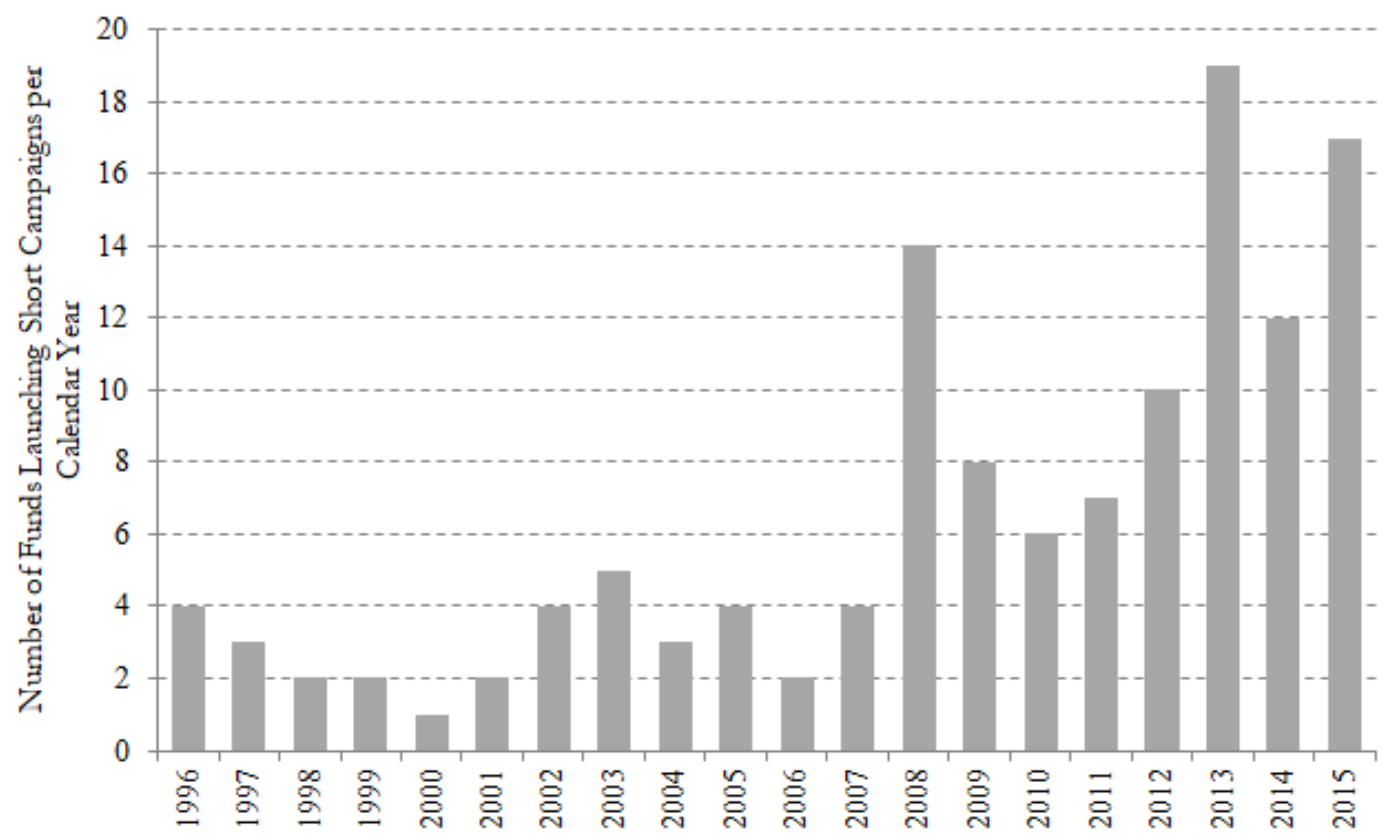

(b) Time Series Distribution of Activists

Figure 1: The Prevalence of Activists' Public Short Selling Campaigns. Panel (a) plots the number of public short selling campaigns initiated each year by activist hedge funds. Panel (b) plots the number of activist hedge funds initiating public short selling campaigns each year. The public short selling campaign data are described in Section 1. 


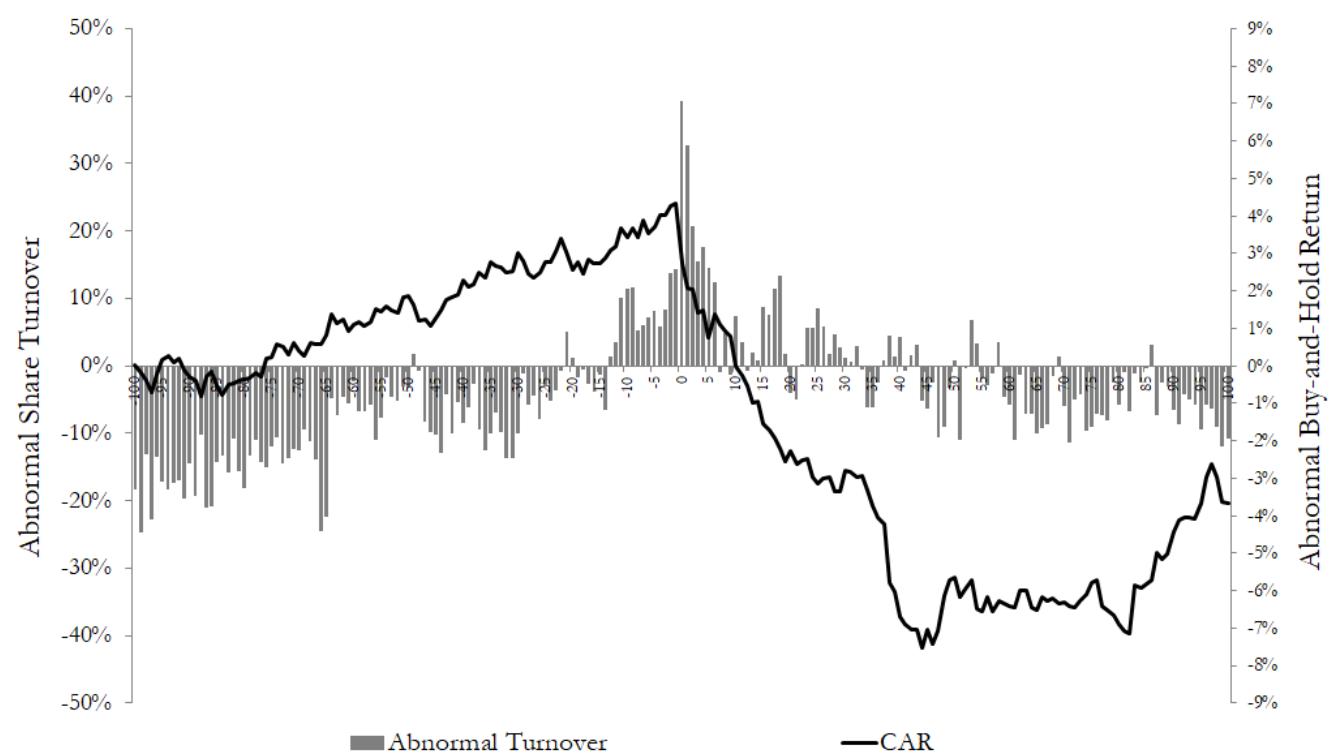

(a) Full Sample.

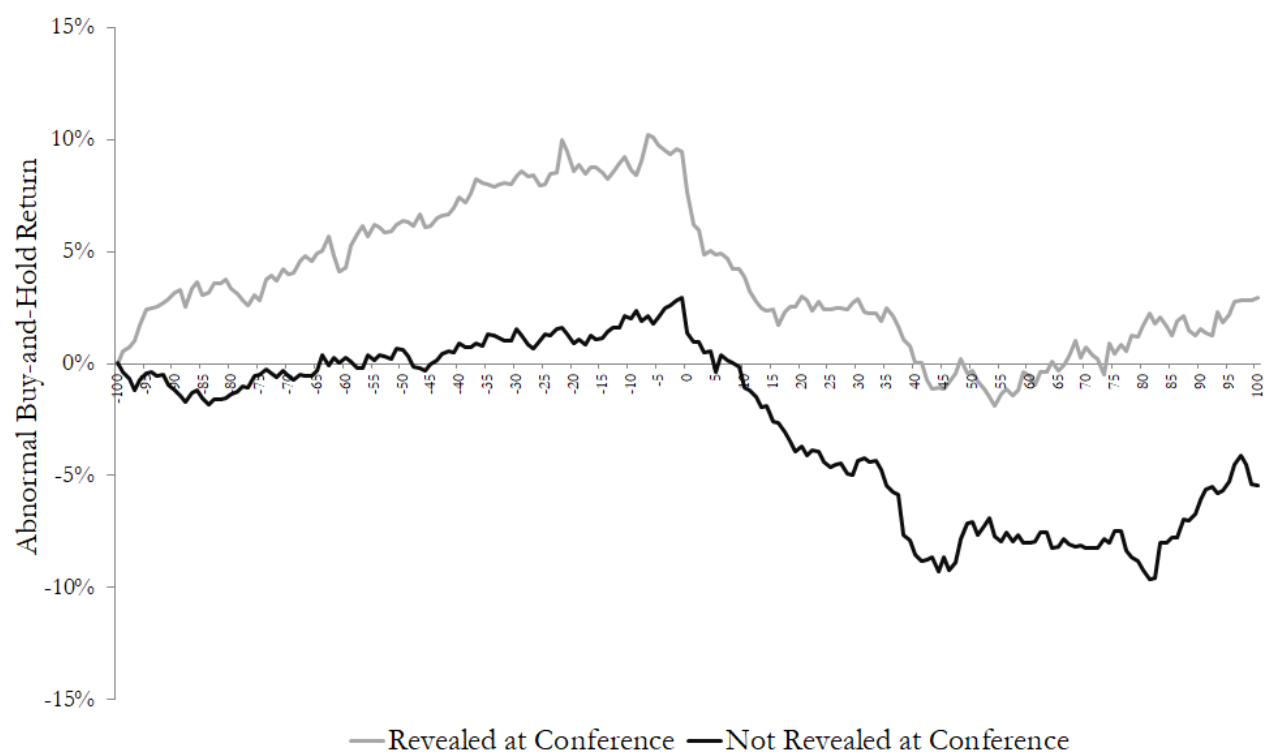

(b) Revelation Method Sub-Samples.

Figure 2: Abnormal Returns for Public Short Selling Campaigns. In panel (a), the dark line plots the cumulative abnormal returns from the three-factor (market, size, and book-to-market) model from 100 days before the announcement of a campaign to 100 days after. The bars plot abnormal share turnover from 100 days before the announcement of a campaign to 100 days after the announcement. In panel (b), the grey and black lines plot the cumulative abnormal returns for public short selling campaigns initially disclosed at investment conferences and disclosed through other means, respectively. The public short selling campaign data are described in Section 1. 


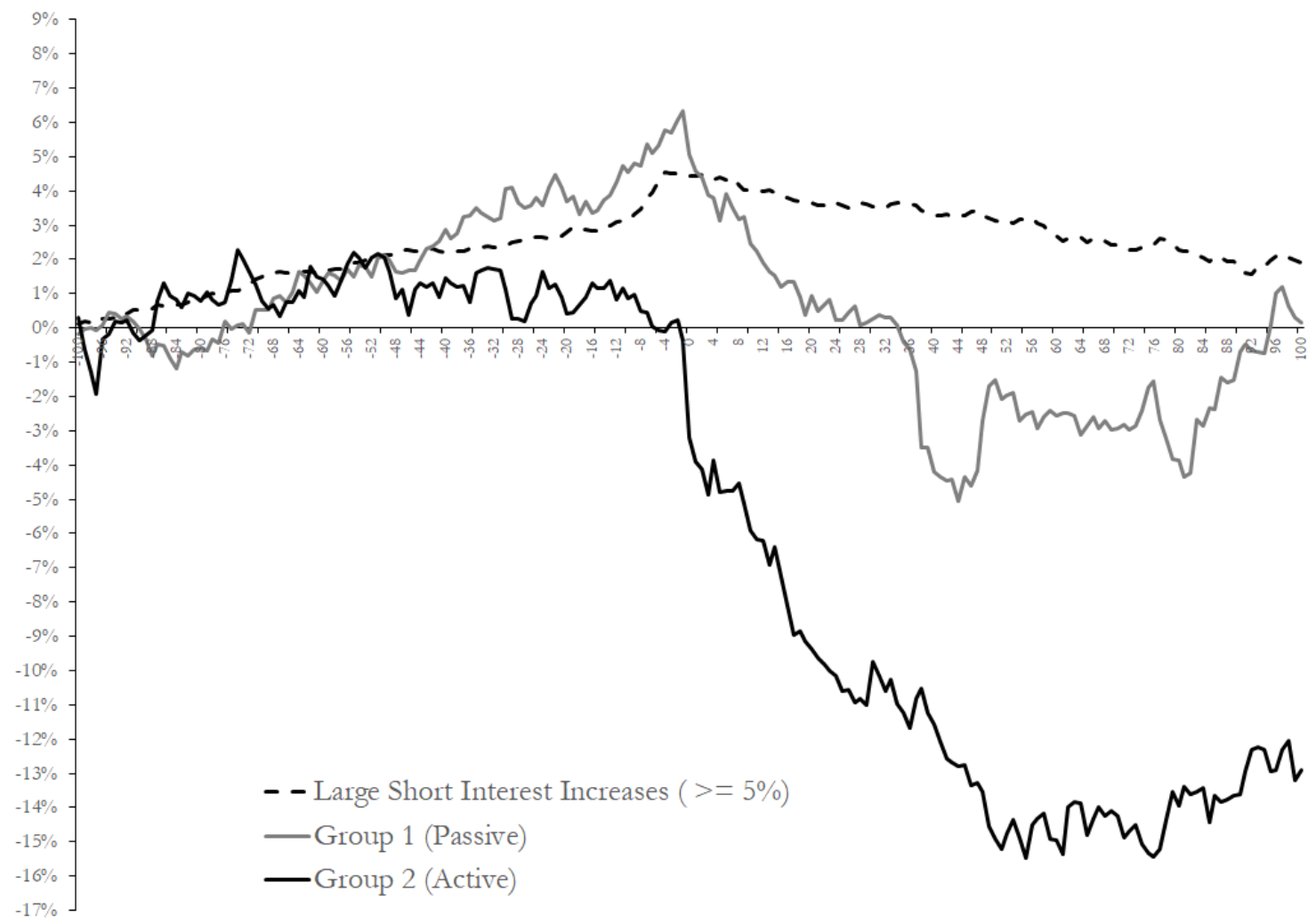

Figure 3: Abnormal Returns for Large Increases in Short Interest and Types of Public Short Selling Campaigns. This figure plots the cumulative abnormal returns from the three-factor (market, size, and book-to-market) model from 100 days before an event to 100 days after. The dashed line plots the cumulative abnormal returns for large (more than $5 \%$ of shares outstanding) increases in short interest. The grey line plots the cumulative abnormal returns for public short selling campaigns with passive allegations. The dark line plots the cumulative abnormal returns for short activism campaigns. Table 1 describes types of allegations. 


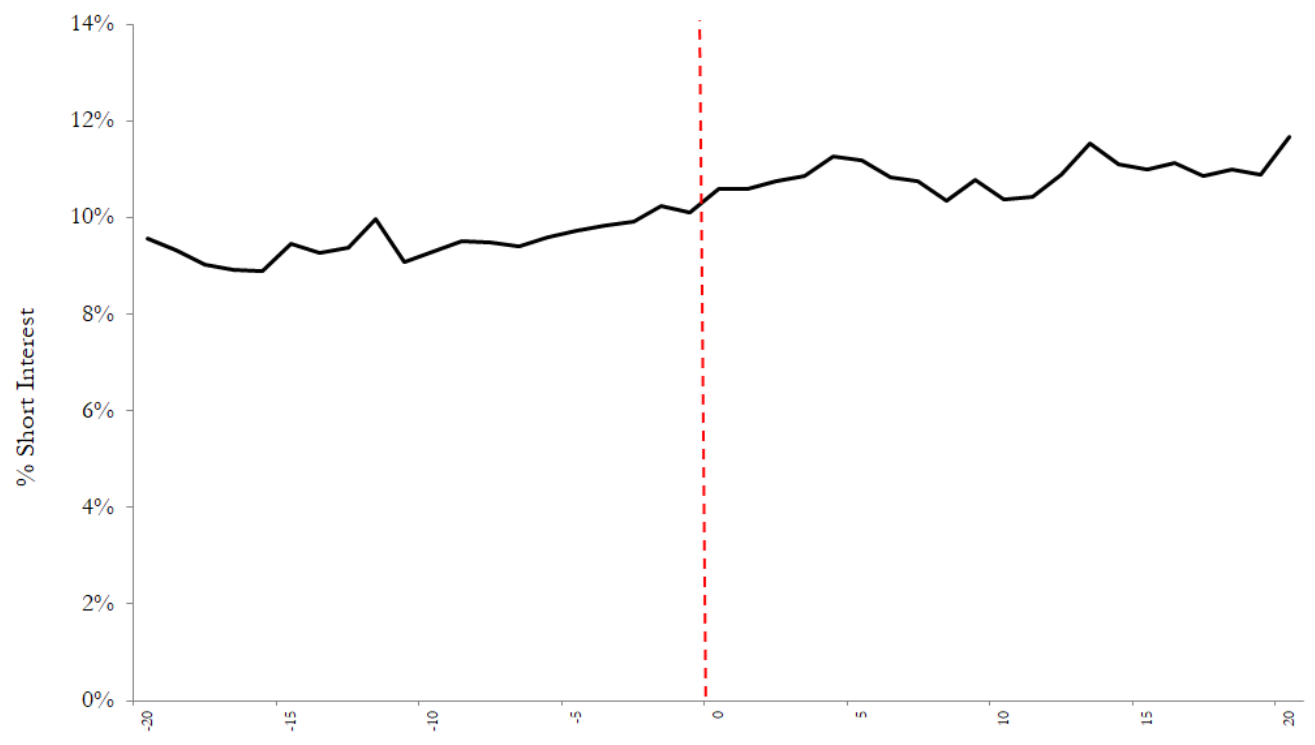

(a) Full Sample

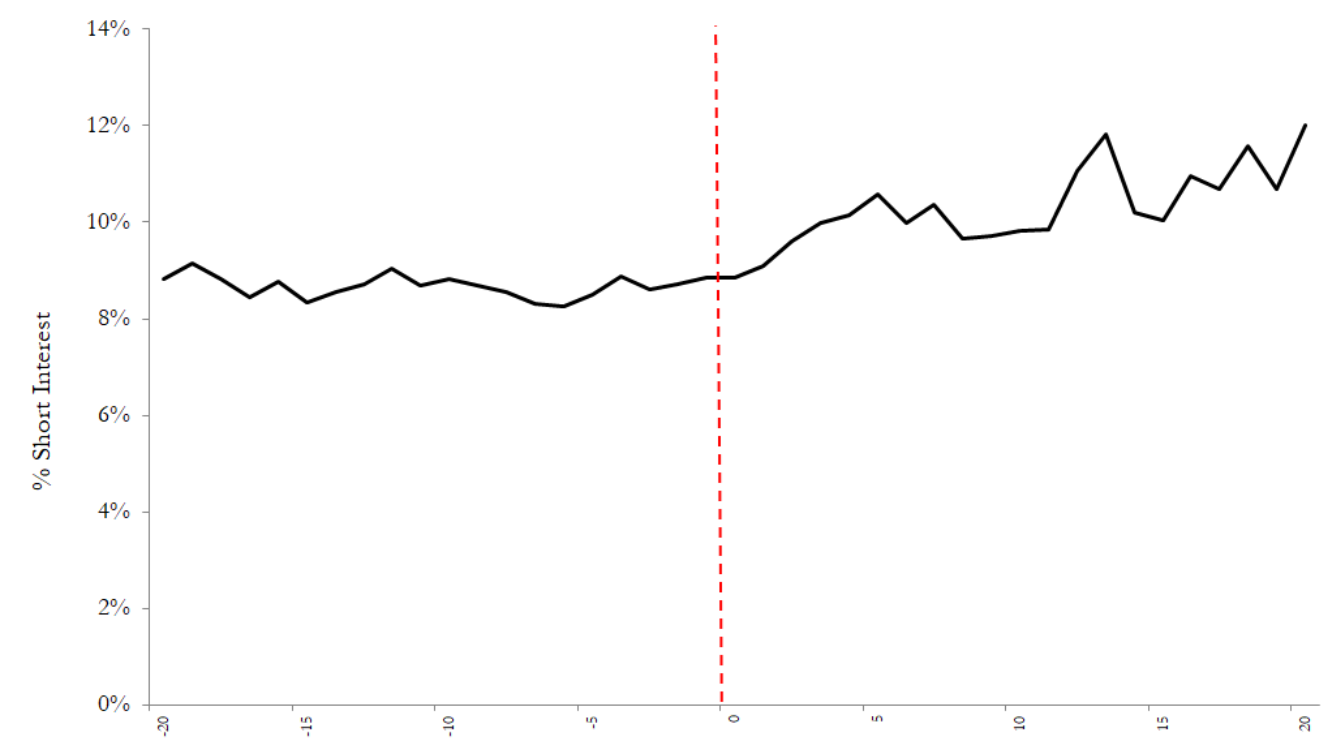

(b) Reveled at Investment Conferences

Figure 4: Short Interest Around Public Short Selling Campaigns by Activist Hedge Funds. In panel (a), the dark line plots the percentage short interest from 20 two-week periods before the announcement of a campaign to 20 two-week periods after. In panel (b), the dark line plots the percentage short interest for public short selling campaigns revealed at investment conference. The public short selling campaign data are described in Section 1. 


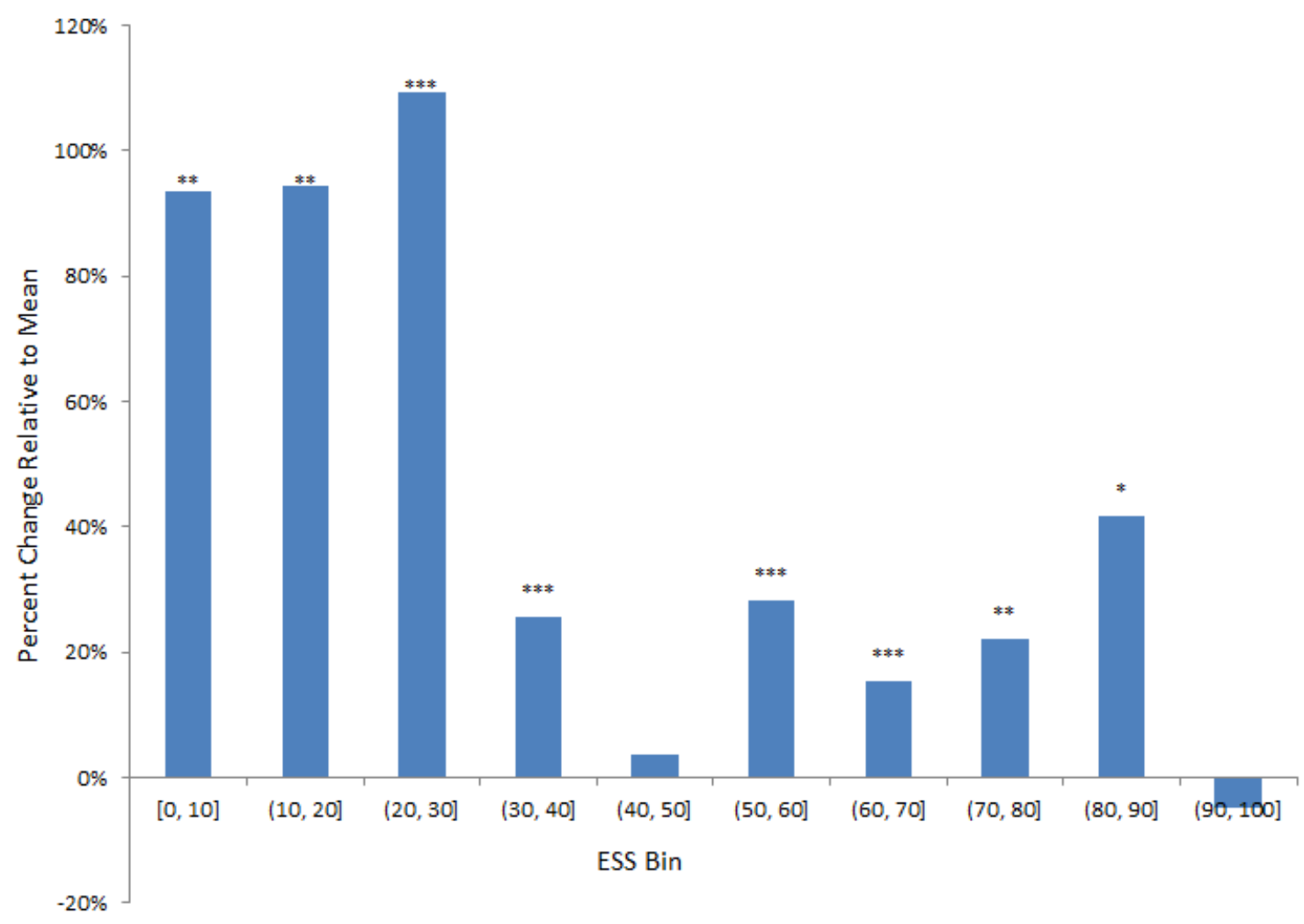

Figure 5: The Tone of Media Coverage. The bars plot the percentage change in the number of articles (relative to the mean) for each Event Sentiment Score (ESS) bin. ESS ranges from 0 to 100, and 50 corresponds to a neutral sentiment. To calculate the changes in media coverage for each ESS Bin, we estimate the following OLS regression for each ESS Bin: $y_{i q}=\alpha_{\text {Target }_{i q}}+X_{i q}^{\prime} \beta+\zeta_{q}+\zeta_{i}+\varepsilon_{i q}$, where $y_{i q}$ is the log-transformed number of articles written about the firm $i$ during year-quarter $q$, Target $_{i q}$ is a dummy variables that indicates the event quarter and the following three quarters, $X_{i q}$ is a vector of control variables, $\zeta_{q}$ are year-quarter fixed effects, and $\zeta_{i}$ are firm fixed effects. Media coverage data are from RavenPack News Analytics and cover 2000-2015 period. The bars report the ratio of $\alpha$ to sample average, minus one. Standard errors are clustered at the firm level. $*$, **, and $* * *$ indicate statistical significance at the $10 \%, 5 \%$, and $1 \%$ levels, respectively. All variables are defined in Table A1. 


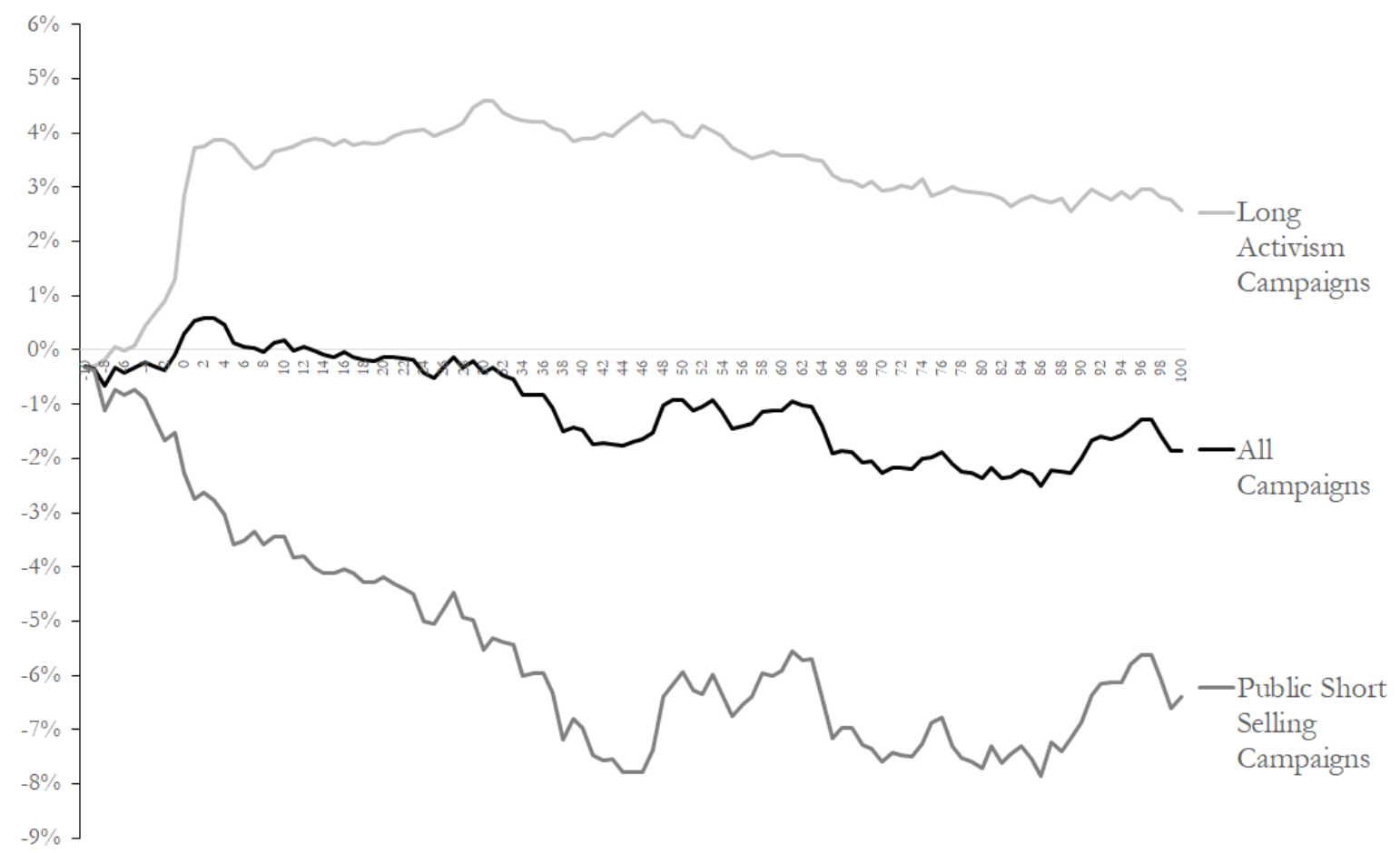

Figure 6: Value-Weighted Abnormal Returns for Long and Short Campaigns. This figure plots the cumulative value-weighted abnormal returns from the three-factor (market, size, and book-to-market) model from 100 days before an event to 100 days after. The light grey line plots the cumulative abnormal returns for activism campaigns. The dark line plots the cumulative abnormal returns for all campaigns publicly disclosed by activist hedge funds. The dark grey line plots the cumulative abnormal returns for public short selling campaigns. 
Table 1: Public Short Selling Campaigns Allegations and Disclosure Methods Panel A reports allegations made by activist hedge funds in public short selling campaigns. These allegations are not mutually exclusive. We split the allegations into two groups. Passive Allegations address the general overvaluation of the firm. Active Allegations ask for a specific change in firm's practices. Panel B reports how activist hedge funds revealed their short positions. The public short selling campaign data are described in Section 1.

Number of campaigns Percentage of campaigns

(1)

(2)

Panel A: Allegations

Passive Allegations:

Financials/Capital Structure

37

$13.0 \%$

Industry/Competitors

69

$24.3 \%$

General Overvaluation

113

$39.8 \%$

Activist Allegations:

Fraud/Accounting

36

$12.7 \%$

Product/Business Model

42

$14.8 \%$

Management/Insider Selling

13

$4.6 \%$

Panel B: Disclosure Methods

Letter to Investors

33

$11.8 \%$

Newspaper/TV

160

$57.1 \%$

Conference

51

$18.2 \%$

White Paper/Other

36

$12.9 \%$ 


\section{Table 2: Target Descriptive Statistics}

This table reports descriptive statistics of public short selling campaigns targets. All variables are defined in Table A1 and are measured during year prior to the campaign. Column (1)-(3) report mean, median, and standard deviation of each variable. Column (4) reports the average difference with a matched firm and column (5) reports the $t$-statistic of the difference. Matched firms are chosen based on 3-digit SIC code and MV and BM deciles. If no match is found, we change the matching criteria to 2-digit SIC code and MV and $\mathrm{BM}$ quintiles. If no match is found, we further change the matching criteria to 2-digit SIC code and MV and BM terciles. Columns (6) and (7) report the median difference and the corresponding Wilcoxon signed-rank test statistics.

\begin{tabular}{|c|c|c|c|c|c|c|c|}
\hline & \multicolumn{3}{|c|}{ Summary Statistics } & \multicolumn{4}{|c|}{ Difference with Matched Firms } \\
\hline & $\begin{array}{l}\text { Mean } \\
(1)\end{array}$ & $\begin{array}{l}\text { Median } \\
(2)\end{array}$ & $\begin{array}{l}\text { SD } \\
(3)\end{array}$ & $\begin{array}{l}\text { Avg. Diff. } \\
\text { (4) }\end{array}$ & $\begin{array}{c}\text { t-stat of Diff. } \\
(5)\end{array}$ & $\begin{array}{c}\text { Median Diff. } \\
(6)\end{array}$ & $\begin{array}{c}\text { Wilcoxon } \\
(7)\end{array}$ \\
\hline \multicolumn{8}{|l|}{ Panel A: Firm-Level Variables } \\
\hline $\log (\mathrm{MV}(\mathrm{t}-1))$ & 8.60 & 8.76 & 1.77 & 2.26 & 17.11 & 2.07 & 11.45 \\
\hline $\mathrm{BM}(\mathrm{t}-1)$ & 0.43 & 0.30 & 0.76 & -0.07 & -1.45 & -0.10 & -4.56 \\
\hline $\mathrm{Q}(\mathrm{t}-1)$ & 2.98 & 1.95 & 2.84 & 0.78 & 4.61 & 0.03 & 3.44 \\
\hline GROWTH (t-1) & 0.20 & 0.15 & 0.39 & 0.09 & 3.23 & 0.02 & 2.79 \\
\hline $\mathrm{ROA}(\mathrm{t}-1)$ & 0.11 & 0.13 & 0.43 & -0.01 & -0.35 & -0.01 & -0.97 \\
\hline $\mathrm{CF}(\mathrm{t}-1)$ & 0.05 & 0.09 & 0.45 & 0.01 & 0.20 & -0.01 & -0.73 \\
\hline $\operatorname{LEV}(\mathrm{t}-1)$ & 0.60 & 0.62 & 0.23 & 0.03 & 2.01 & 0.04 & 2.53 \\
\hline CASH (t-1) & 0.19 & 0.14 & 0.20 & 0.001 & -0.20 & -0.01 & -0.90 \\
\hline DIVYLD (t-1) & 0.02 & 0.00 & 0.04 & 0.002 & 0.66 & -0.002 & -2.29 \\
\hline PAYOUT (t-1) & 0.25 & 0.00 & 0.52 & -0.04 & -0.93 & -0.04 & -3.23 \\
\hline $\log (1+\operatorname{ANALYST}(\mathrm{t}-1))$ & 1.88 & 2.05 & 0.82 & 0.13 & 2.20 & 0.15 & 3.22 \\
\hline $\operatorname{INST}(\mathrm{t}-1)$ & 0.66 & 0.72 & 0.31 & 0.05 & 1.55 & 0.08 & 3.49 \\
\hline STKRET (t-1) & 0.32 & 0.08 & 0.83 & 0.15 & 2.69 & -0.02 & 0.83 \\
\hline AMIHUD (t-1) & 0.03 & 0.02 & 0.06 & -0.02 & -4.88 & -0.01 & -7.82 \\
\hline SHORTINT (t-1) & 0.09 & 0.05 & 0.09 & 0.04 & 5.90 & 0.01 & 4.83 \\
\hline FTD $(\mathrm{t}-1)$ & 0.0005 & 0.0006 & 0.0014 & 0.0002 & 1.88 & 0.0000 & 1.36 \\
\hline \multicolumn{8}{|l|}{ Panel B: Event-Level Variables } \\
\hline Lawsuit $=1$ & 0.11 & 0.00 & 0.31 & & & & \\
\hline $\log (1+\#$ Lawsuits $)$ & 0.10 & 0.00 & 0.30 & & & & \\
\hline $\log (1+\#$ Articles $)$ & 1.74 & 1.95 & 1.39 & & & & \\
\hline Average Event Sentiment Score & 52.00 & 50.00 & 5.57 & & & & \\
\hline Public Short Selling Dummy & 0.12 & 0.00 & 0.32 & & & & \\
\hline
\end{tabular}




\section{Table 3: Predicting Public Short Selling Campaigns}

Column (1) reports estimated coefficients of the probit regression: $\operatorname{Pr}\left(P S S_{i t}=1\right)=$ $\Phi\left(X_{i t} \alpha_{1}+\zeta_{t}+\zeta_{j}+\varepsilon_{i t}\right)$, where the dependent variable $P S S_{i t}$ is a dummy variable equal to one if the company is targeted in a public short selling campaign during the year, $\Phi$ is the cumulative normal distribution, $X_{i t}$ is a vector of lagged covariates, $\zeta_{t}$ are year fixed effects, and $\zeta_{j}$ are industry fixed effects. Columns (2)-(4) report estimated coefficients of the OLS regression: $P S S_{i t}=X_{i t} \alpha_{2}+\zeta_{t}+\zeta_{j}+\varepsilon_{i t}$. Standard errors are reported in the parentheses and are clustered at the firm level. These regressions cover all Compustat firm-year observations from 1996 through 2015, and include both event and non-event observations. All independent variables are defined in Table A1. *,**, and *** indicate statistical significance at the $10 \%, 5 \%$, and $1 \%$ levels, respectively.

\begin{tabular}{|c|c|c|c|c|}
\hline Model: & $\begin{array}{l}\text { Probit } \\
\text { (1) }\end{array}$ & $\begin{array}{l}\text { OLS } \\
(2)\end{array}$ & $\begin{array}{c}\text { OLS } \\
(3)\end{array}$ & $\begin{array}{c}\text { OLS } \\
(4)\end{array}$ \\
\hline $\log (\mathrm{MV}(\mathrm{t}-1))$ & $\begin{array}{c}0.0003^{* * *} \\
(0.0000)\end{array}$ & $\begin{array}{c}0.0008^{* * *} \\
(0.0001)\end{array}$ & $\begin{array}{c}0.0010^{* * *} \\
(0.0002)\end{array}$ & $\begin{array}{c}0.0010^{* * *} \\
(0.0002)\end{array}$ \\
\hline $\mathrm{Q}(\mathrm{t}-1)$ & $\begin{array}{c}0.0000^{* * *} \\
(0.0000)\end{array}$ & $\begin{array}{c}0.0002^{* *} \\
(0.0001)\end{array}$ & $\begin{array}{c}0.0002^{* *} \\
(0.0001)\end{array}$ & $\begin{array}{c}0.0002^{* *} \\
(0.0001)\end{array}$ \\
\hline GROWTH (t-1) & $\begin{array}{c}0.0004^{* * *} \\
(0.0001)\end{array}$ & $\begin{array}{c}0.0008^{*} \\
(0.0004)\end{array}$ & $\begin{array}{c}0.0007^{*} \\
(0.0004)\end{array}$ & $\begin{array}{c}0.0009^{* *} \\
(0.0004)\end{array}$ \\
\hline $\mathrm{ROA}(\mathrm{t}-1)$ & $\begin{array}{c}0.0000 \\
(0.0002)\end{array}$ & $\begin{array}{c}0.0001 \\
(0.0006)\end{array}$ & $\begin{array}{c}0.0001 \\
(0.0006)\end{array}$ & $\begin{array}{c}0.0000 \\
(0.0006)\end{array}$ \\
\hline $\operatorname{LEV}(\mathrm{t}-1)$ & $\begin{array}{c}0.0005^{* *} \\
(0.0002)\end{array}$ & $\begin{array}{c}0.0018^{* * *} * \\
(0.0006)\end{array}$ & $\begin{array}{c}0.0028^{* * *} \\
(0.0008)\end{array}$ & $\begin{array}{c}0.0021^{* * *} \\
(0.0008)\end{array}$ \\
\hline DIVYLD (t-1) & $\begin{array}{c}0.0012 \\
(0.0013)\end{array}$ & $\begin{array}{c}-0.0050 \\
(0.0037)\end{array}$ & $\begin{array}{c}0.0020 \\
(0.0042)\end{array}$ & $\begin{array}{l}-0.0015 \\
(0.0045)\end{array}$ \\
\hline $\log (1+\operatorname{ANALYST}(\mathrm{t}-1))$ & $\begin{array}{c}0.0000 \\
(0.0001)\end{array}$ & $\begin{array}{l}0.0005^{*} \\
(0.0003)\end{array}$ & $\begin{array}{c}0.0005 \\
(0.0003)\end{array}$ & $\begin{array}{c}0.0004 \\
(0.0003)\end{array}$ \\
\hline INST (t-1) & $\begin{array}{c}0.0005^{* * *} \\
(0.0002)\end{array}$ & $\begin{array}{c}-0.0010 \\
(0.0008)\end{array}$ & $\begin{array}{c}-0.0020^{* *} \\
(0.0008)\end{array}$ & $\begin{array}{c}-0.0020^{* *} \\
(0.0008)\end{array}$ \\
\hline Observations & 91,991 & 91,991 & 91,991 & 91,539 \\
\hline Pseudo $R^{2} / R^{2}$ & 0.158 & 0.004 & 0.012 & 0.072 \\
\hline $\begin{array}{l}\text { Fixed Effects: } \\
\text { Year FE } \\
\text { Industry FE } \\
\text { Industry-Year FE }\end{array}$ & $\begin{array}{l}\text { No } \\
\text { No } \\
\text { No }\end{array}$ & $\begin{array}{l}\text { Yes } \\
\text { No } \\
\text { No }\end{array}$ & $\begin{array}{l}\text { Yes } \\
\text { Yes } \\
\text { No }\end{array}$ & $\begin{array}{l}\text { No } \\
\text { No } \\
\text { Yes }\end{array}$ \\
\hline
\end{tabular}




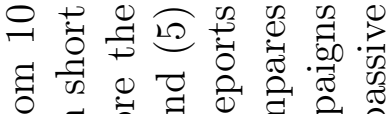

․․

.

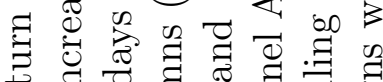

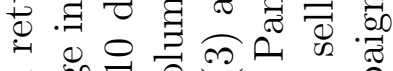

శี

过

范

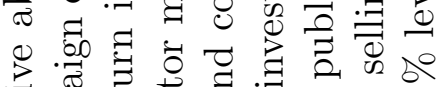

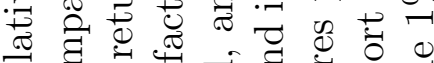

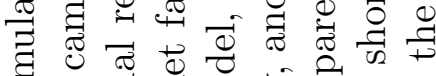

व $\approx$ व

की

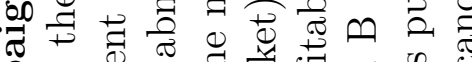

ڤิ

藏

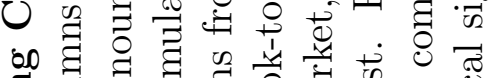

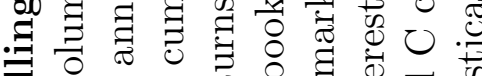

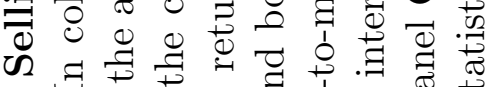

प

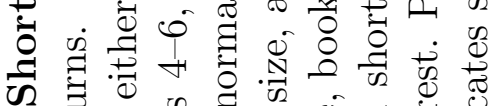

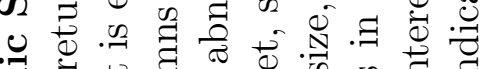

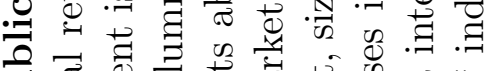

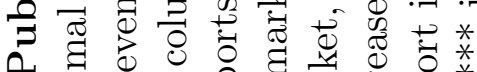

A

पे 염

प

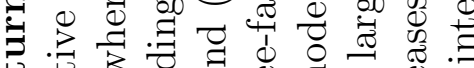

晒 3.

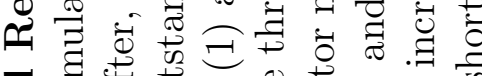

ส

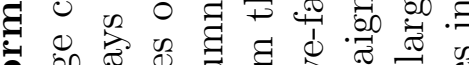

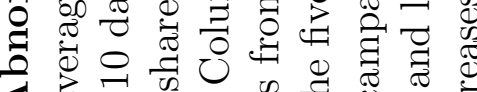

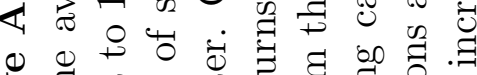

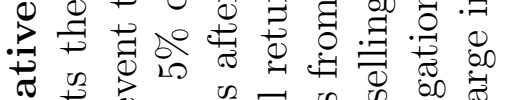

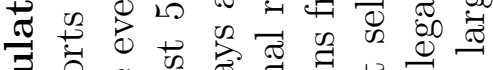

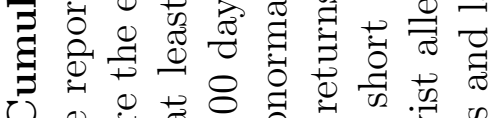

임

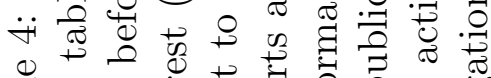

es

$\nabla$

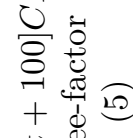

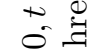

।

$\pm$

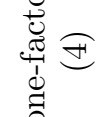

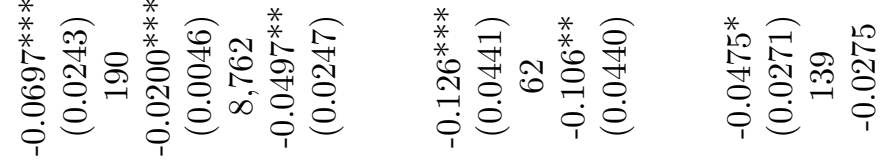

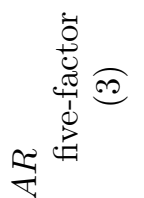

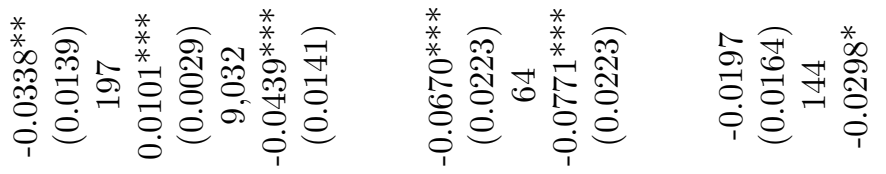

응 훙

$+\underset{d}{+} \widehat{\Theta}$

它

1

$\pm$

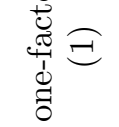

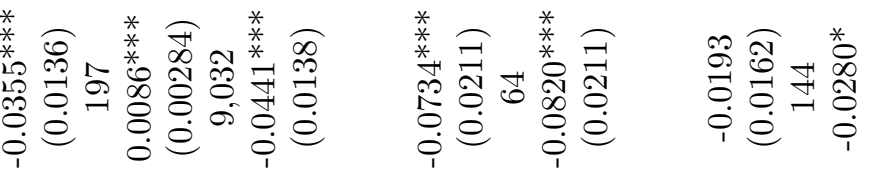

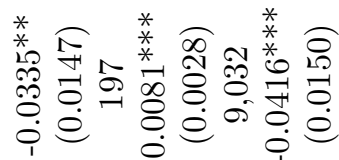

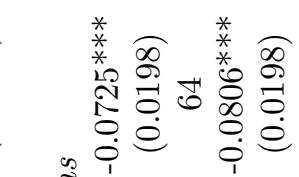

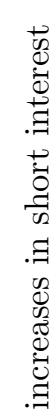

象

हुँ

हु

崫

(1)

कृ

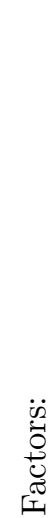

$\because$ क थ

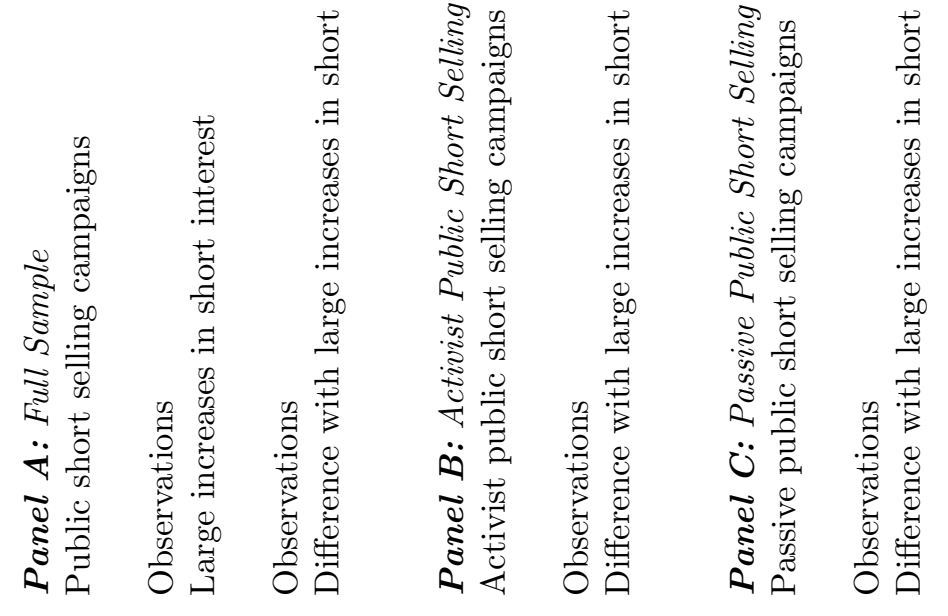

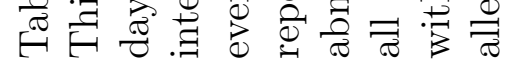




\section{Table 5: Short Interest and Public Short Campaigns}

This table reports changes in short interest around public short selling campaigns. Panel A reports estimates of the following OLS regression: $y_{i t}=\alpha \operatorname{Target}_{i t}+\zeta_{i}+\varepsilon_{i t}$, where $y_{i t}$ is short interest for event $i$ and period $t$, where a period is two weeks. Post $t_{i t}$ is a dummy variable that indicates observations after the announcement of a public short selling campaign, and $\zeta_{i}$ are event fixed effects. The regression cover observation from 10 periods before the announcement of a campaign to 10 periods after. Panel B reports estimates for a sub-sample of public short selling campaigns reveled at investment conferences. Robust standard errors are clustered by event and reported in the parentheses. ${ }^{*},{ }^{* *}$, and ${ }^{* * *}$ indicate statistical significance at the $10 \%, 5 \%$, and $1 \%$ levels, respectively. All independent variables are defined in Table A1.

\begin{tabular}{lcc}
\hline \hline Dependent Variable: Short & $\begin{array}{c}\text { Interest } \\
(1)\end{array}$ & $(2)$ \\
& & \\
\hline Target & $\begin{array}{c}0.0098^{*} \\
(0.0052)\end{array}$ & $\begin{array}{c}0.0138^{* * *} \\
(0.0044)\end{array}$ \\
Constant & $\begin{array}{c}0.0980^{* * *} \\
(0.0075)\end{array}$ & \\
& & \\
Observations & 3,829 & 3,829 \\
$R^{2}$ & 0.002 & 0.853 \\
Fixed Effects: & & \\
Event FE & No & Yes \\
\hline \hline
\end{tabular}




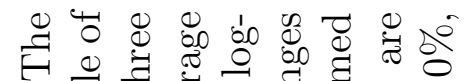

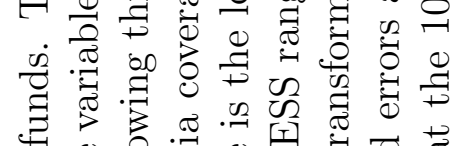

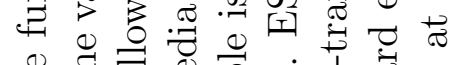

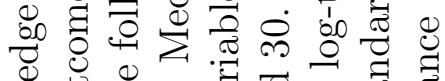

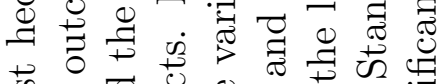
. 获

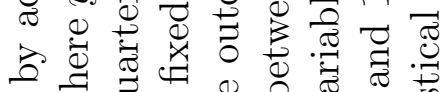

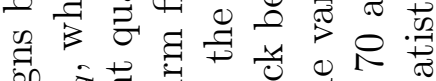
.

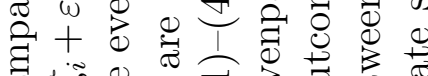

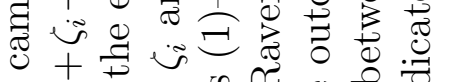

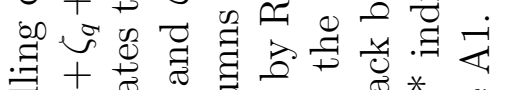
o 0 .

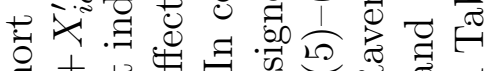

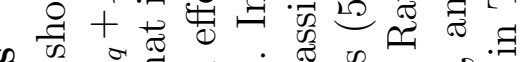

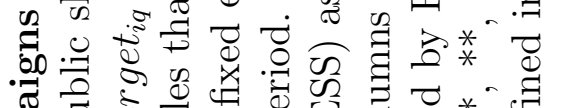

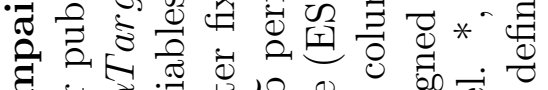

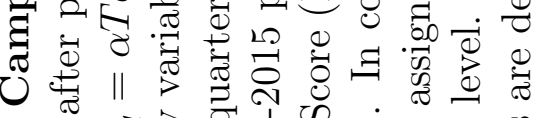

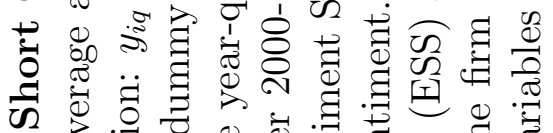
৩ ठठ

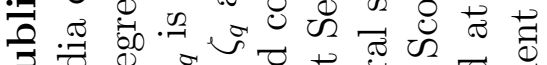
म.

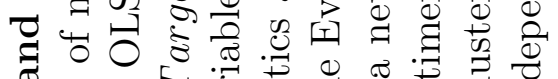

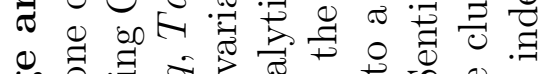

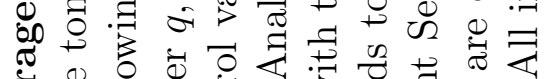

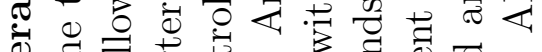

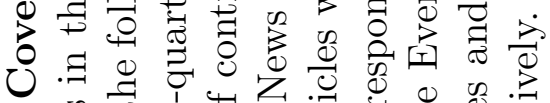
y झ 买 లే

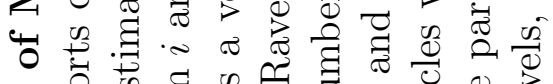

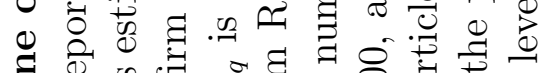

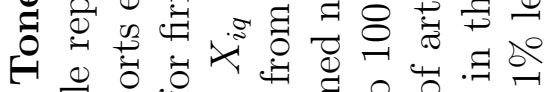

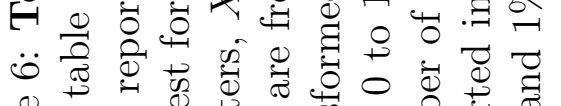

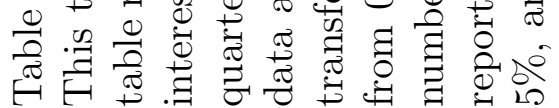

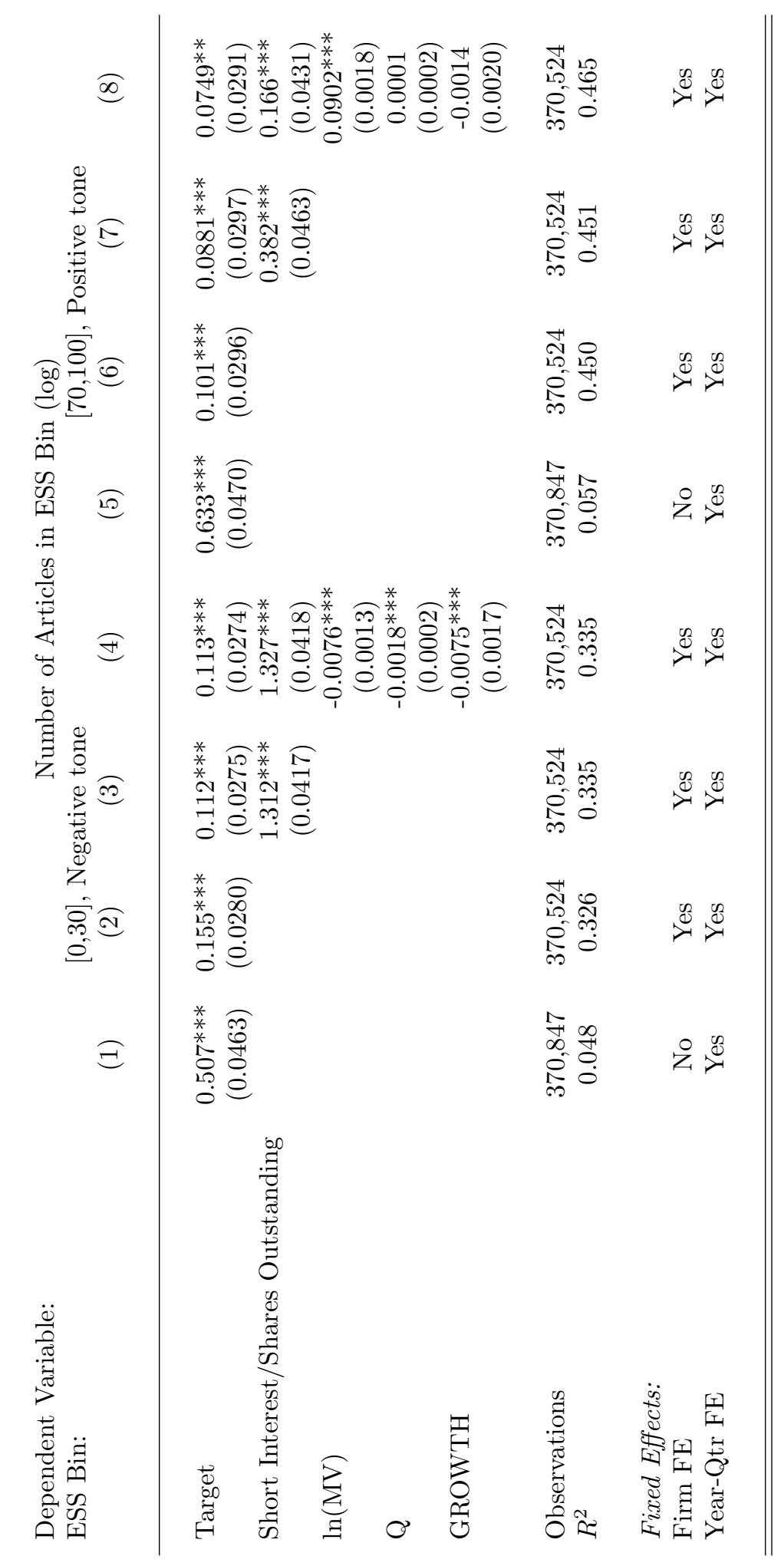




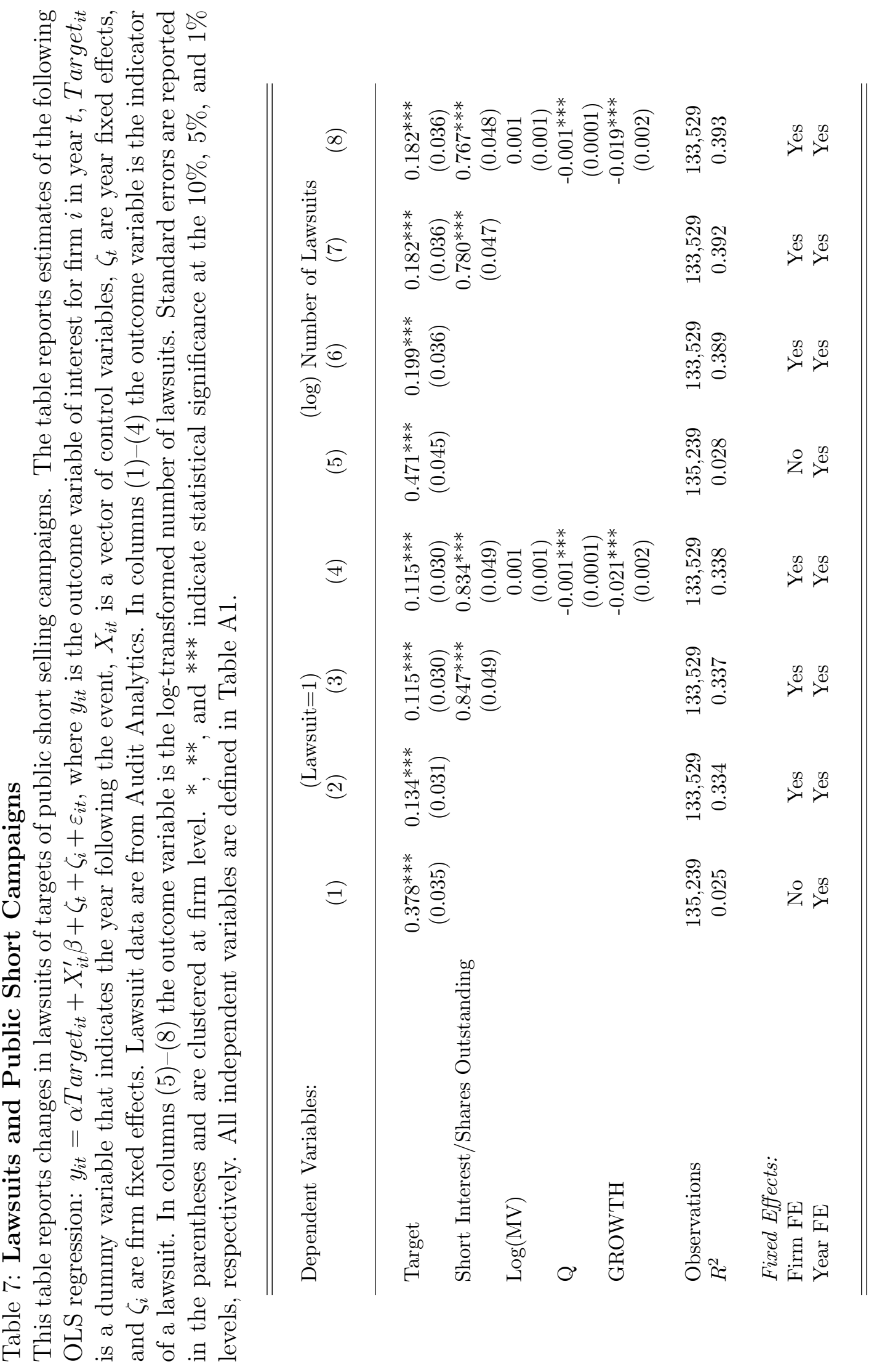




\section{Table 8: Long Activism Experience and Public Short Selling Campaigns}

This table documents the relation between long shareholder activism and public short selling campaigns by activist hedge funds. Activist hedge funds are assigned to quartiles based on the number of long activism campaigns. For each quartile, column (2) reports the average number of long activism campaigns, column (3) reports the media number of long activism campaigns, and column (4) reports the average number of public short selling campaigns.

\begin{tabular}{cccc}
\hline \hline $\begin{array}{c}\text { Long Activism } \\
\text { Quartiles } \\
(1)\end{array}$ & $\begin{array}{c}\text { Average Number of } \\
\text { Activism Campaigns } \\
(2)\end{array}$ & $\begin{array}{c}\text { Median Number of } \\
\text { Activism Campaigns }\end{array}$ & $\begin{array}{c}\text { Average Number of } \\
\text { Short Campaigns } \\
(4)\end{array}$ \\
\hline & & & \\
1 & 1 & 1 & 0.036 \\
2 & 2.36 & 2 & 0.348 \\
3 & 4.7 & 5 & 1.222 \\
4 & 17 & 12 & 1.034 \\
\hline \hline
\end{tabular}


Supplemental Internal Materials for the paper "Public Short Selling by Activist Hedge Funds"

by Ian Appel, Jordan Bulka, and Vyacheslav Fos 
Appendix A. Supplemental Tables and Figures 


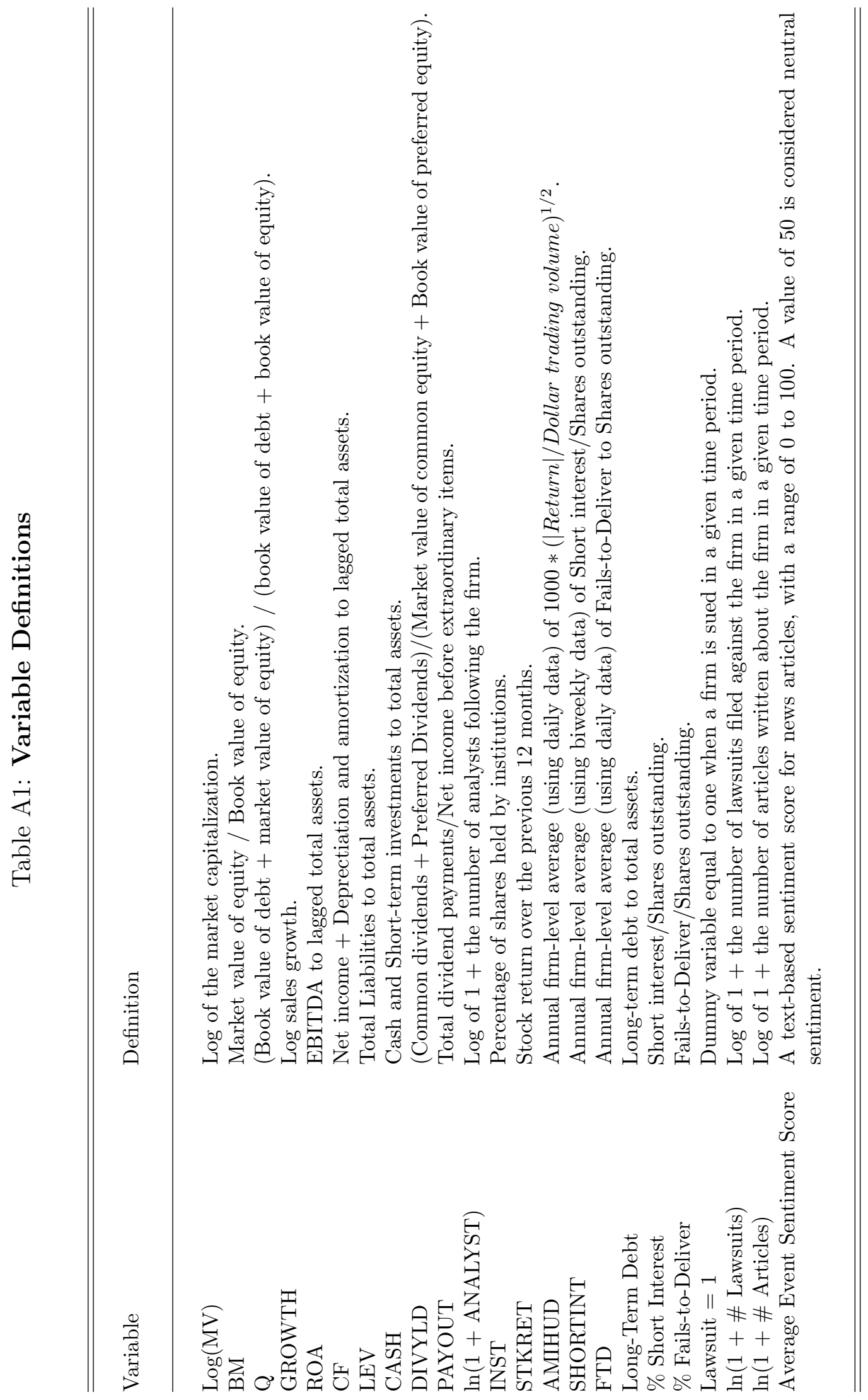




\section{Table A2: Long Activism Tactics and Public Short Selling Campaigns}

This table documents the relation between engagements in public short selling campaigns and the tactics and outcomes of long activism campaigns. Shareholder activism data are an updated sample from Brav et al. (2008). Panel A reports tactics adopted by activism hedge funds as well as beneficial ownership disclosed in Schedule 13D. Panel B reports activism campaign outcomes. Column (1) reports tactics and outcomes for activist hedge funds that have public short selling experience. Column (2) reports tactics and outcomes for activist hedge funds that do not have public short selling experience. Columns (3) and (4) report the differences and $t$-statistics of the differences.

\begin{tabular}{|c|c|c|c|c|}
\hline Variable & $\begin{array}{c}\text { Activists with Public } \\
\text { Short Selling Experience } \\
\text { (43 funds) } \\
(1)\end{array}$ & $\begin{array}{l}\text { Activists without Public } \\
\text { Short Selling Experience } \\
\text { (291 funds) } \\
(2)\end{array}$ & Difference & $t$-statistic \\
\hline \multicolumn{5}{|l|}{ Panel A: Activism Tactics } \\
\hline Communication & 0.173 & 0.193 & -0.019 & 0.95 \\
\hline Proposal & 0.374 & 0.308 & 0.066 & 2.70 \\
\hline Proxy & 0.084 & 0.101 & -0.017 & 1.09 \\
\hline Lawsuit & 0.036 & 0.035 & 0.001 & 0.14 \\
\hline Takeover & 0.046 & 0.031 & 0.015 & 1.60 \\
\hline Threat & 0.089 & 0.085 & 0.004 & 0.24 \\
\hline Seek Board Representation & 0.173 & 0.188 & -0.014 & 0.71 \\
\hline Hostile & 0.251 & 0.207 & 0.044 & 2.05 \\
\hline Initially Hostile & 0.137 & 0.089 & 0.048 & 3.09 \\
\hline Objective $=$ Sale & 0.223 & 0.167 & 0.057 & 2.85 \\
\hline Objective $=$ Business Strategy & 0.216 & 0.172 & 0.044 & 2.21 \\
\hline Objective $=$ Governance & 0.321 & 0.317 & 0.005 & 0.19 \\
\hline$\%$ Ownership on 13D & 0.102 & 0.091 & 0.011 & 2.38 \\
\hline \multicolumn{5}{|l|}{ Panel B: Activism Outcomes } \\
\hline Succeed & 0.193 & 0.172 & 0.021 & 1.01 \\
\hline Fail & 0.085 & 0.058 & 0.027 & 2.07 \\
\hline Settle & 0.126 & 0.123 & 0.003 & 0.17 \\
\hline
\end{tabular}




\section{Table A3: Reputational Effects of Public Short Campaigns}

This table reports the relation between abnormal returns around activism campaign announcements and abnormal returns around public short selling campaign announcements. We report estimates of regression (4): $C A R_{f i}^{\text {long }}=\alpha C A R_{f i}^{\text {short }}+X_{i}^{\prime} \delta+\zeta_{t}+\zeta_{f}+\varepsilon_{i}$, where $C A R_{i}^{\text {long }}$ is the abnormal return for long campaign $i$ for activist hedge fund $f, C A R_{f}^{\text {short }}$ is the abnormal return for public short selling campaigns for fund $f$ in the preceding 12 months, $X_{i}$ is a vector of control variables (Long-Term Debt, $\ln (M V)$, ObjGeneral, ObjBusStrategy, ObjCapStructure, ObjSales, ObjGov, and Hostile), $\zeta_{t}$ are year fixed effects, and $\zeta_{f}$ are activist hedge fund fixed effects. Columns (1)-(3) report abnormal returns from the market factor model, columns (4)-(6) report abnormal returns from the three-factor (market, size, and book-to-market) model, and columns (7)-(9) report abnormal returns from the five-factor model (market, size, book-to-market, profitability, and investment). Standard errors are reported in the parentheses and are clustered at the fund level. *, **, and $* * *$ indicate statistical significance at the $10 \%, 5 \%$, and $1 \%$ levels, respectively. All independent variables are defined in Table A1.

\begin{tabular}{|c|c|c|c|c|c|c|c|c|c|}
\hline \multicolumn{10}{|c|}{ Dependent Variable: $C A R^{\text {long }}$} \\
\hline & \multirow{2}{*}{\multicolumn{2}{|c|}{$\begin{array}{c}\text { CAPM } \\
(2)\end{array}$}} & \multirow[b]{2}{*}{$(3)$} & \multicolumn{3}{|c|}{ 3-factor model } & \multicolumn{3}{|c|}{ 5-factor model } \\
\hline & & & & (4) & $(5)$ & (6) & (7) & (8) & (9) \\
\hline$C A R^{\text {short }}$ & $\begin{array}{l}0.0264 \\
(0.189)\end{array}$ & $\begin{array}{c}0.358 \\
(0.256)\end{array}$ & $\begin{array}{c}0.404 \\
(0.265)\end{array}$ & $\begin{array}{l}0.0363 \\
(0.195)\end{array}$ & $\begin{array}{c}0.415 \\
(0.275)\end{array}$ & $\begin{array}{c}0.460 \\
(0.288)\end{array}$ & $\begin{array}{l}0.0618 \\
(0.193)\end{array}$ & $\begin{array}{l}0.454^{*} \\
(0.274)\end{array}$ & $\begin{array}{c}0.499^{*} \\
(0.285)\end{array}$ \\
\hline Observations & 2,247 & 2,128 & 1,942 & 2,247 & 2,128 & 1,942 & 2,247 & 2,128 & 1,942 \\
\hline$R^{2}$ & 0.010 & 0.149 & 0.174 & 0.009 & 0.146 & 0.169 & 0.011 & 0.150 & 0.168 \\
\hline \multicolumn{10}{|c|}{ Controls and Fixed Effects: } \\
\hline Controls & No & No & Yes & No & No & Yes & No & No & Yes \\
\hline Fund FE & No & Yes & Yes & No & Yes & Yes & No & Yes & Yes \\
\hline Year FE & Yes & Yes & Yes & Yes & Yes & Yes & Yes & Yes & Yes \\
\hline
\end{tabular}




\section{Table A4: Public Short Selling Campaigns as Hedges of Long Positions}

This table documents whether public short selling campaigns are used to hedge existing long positions of activist hedge funds. The table reports estimates of regression (5), in which we regress an indicator for public short selling targeting on the activists' portfolio weights in competing firms (based on classifications by Hoberg and Phillips (2010) and Hoberg and Phillips (2016)). Columns (3) and (6) include control variables (log of market cap, Q, and sales growth rate). Standard errors are reported in the parentheses and are clustered by fund-firm pairs. $*, * *$, and $* * *$ indicate statistical significance at the $10 \%, 5 \%$, and $1 \%$ levels, respectively. All independent variables are defined in Table A1.

\begin{tabular}{|c|c|c|c|c|c|c|}
\hline Dependent Variable: Public Short Selli & $\begin{array}{l}\text { ng Campaign } \\
\text { (1) }\end{array}$ & $\begin{array}{r}\text { Target } \\
(2)\end{array}$ & $(3)$ & $(4)$ & $(5)$ & $(6)$ \\
\hline Portfolio Weight in Competitors ( $\mathrm{t}-1$ ) & $\begin{array}{c}0.0007 \\
(0.0004)\end{array}$ & $\begin{array}{c}0.0004 \\
(0.0004)\end{array}$ & $\begin{array}{c}0.0002 \\
(0.0006)\end{array}$ & & & \\
\hline $\begin{array}{l}\text { Portfolio Weight in Competitors (t-1), } \\
\text { Score Weighted }\end{array}$ & & & & $\begin{array}{c}0.0075 \\
(0.0053)\end{array}$ & $\begin{array}{c}0.0042 \\
(0.0054)\end{array}$ & $\begin{array}{c}0.0012 \\
(0.0071)\end{array}$ \\
\hline $\begin{array}{l}\text { Observations } \\
R^{2}\end{array}$ & $\begin{array}{c}10,900,264 \\
0.000\end{array}$ & $\begin{array}{c}10,900,264 \\
0.001\end{array}$ & $\begin{array}{c}6,149,276 \\
0.002\end{array}$ & $\begin{array}{c}10,900,264 \\
0.000\end{array}$ & $\begin{array}{c}10,900,264 \\
0.001\end{array}$ & $\begin{array}{c}6,149,276 \\
0.002\end{array}$ \\
\hline $\begin{array}{l}\text { Controls and Fixed Effects: } \\
\text { Controls } \\
\text { Fund FE } \\
\text { Firm FE } \\
\text { Year-Qtr FE }\end{array}$ & $\begin{array}{l}\text { No } \\
\text { No } \\
\text { No } \\
\text { Yes }\end{array}$ & $\begin{array}{l}\text { No } \\
\text { Yes } \\
\text { Yes } \\
\text { Yes }\end{array}$ & $\begin{array}{c}\text { Yes } \\
\text { Yes } \\
\text { Yes } \\
\text { Yes }\end{array}$ & $\begin{array}{l}\text { No } \\
\text { No } \\
\text { No } \\
\text { Yes }\end{array}$ & $\begin{array}{l}\text { No } \\
\text { Yes } \\
\text { Yes } \\
\text { Yes }\end{array}$ & $\begin{array}{l}\text { Yes } \\
\text { Yes } \\
\text { Yes } \\
\text { Yes }\end{array}$ \\
\hline
\end{tabular}




\section{Appendix B. Information Acquisition Synergies: Theoretical Framework}

In this section, we provide a theoretical framework to illustrate how access to activism technology (i.e., the ability to increase firm value when buying a stock) increases the expected payoff from disclosure of short positions. The key insight of this framework is that, because activists can use information for both trading and activism purposes, activism technology creates higher incentives to collect information prior to making an investment decision. This, in turn, makes activists more likely to acquire information that is sufficiently negative to justify the public disclosure of short positions.

Formally, investor $\mathcal{A}$ decides whether to acquire information about a public firm.

$\mathcal{A}$ can generate an expected trading profit $c_{i}$ if he invests $\frac{c_{i}^{2}}{2}$ in information acquisition. While we do not explicitly model the trading environment, the presence of noise traders can generate positive expected trading profits for informed investors (e.g., Kyle, 1985). If $\mathcal{A}$ learns that the firm is undervalued (over-valued), he can purchase (short) shares and realize trading profits after the mispricing is corrected. We assume that the probability of the firm being undervalued is $\gamma$ and the probability of the firm being overvalued is $(1-\gamma)$.

If $\mathcal{A}$ has access to an activism technology, he can realize an additional trading profit on long positions. Specifically, we assume that if the firm is undervalued, $\mathcal{A}$ can gain an additional profit $\alpha c_{i}$ by running a long activism campaign. Because the benefits of activism are increasing in $\alpha$, this parameter can be interpreted as a measure of the skill or experience of activists. If $\mathcal{A}$ takes a long position in the firm (either because the firm is undervalued or because $\mathcal{A}$ engages in activism campaign), he is required to publicly disclose the position. This assumption is consistent with the disclosure requirements under Schedules $13 \mathrm{D}$ and 13F of the Securities Exchange Act of 1934.

Also consistent with US securities law, we assume disclosure of a short position is voluntary. Jank et al. (2016) and Jones et al. (2016) provide evidence consistent with public disclosure of short positions being costly for investors. We therefore assume that $\mathcal{A}$ incurs a private cost $c_{\text {short }}$ if he publicly discloses short position. The benefit of public 
disclosure is $s c_{i}$, where $s>0$. This parameter captures changes in the behavior of other stakeholders that are driven by public disclosure of short positions by activists.

Our objective is to understand how the access to activism technology affects $\mathcal{A}$ 's incentive to publicly disclose short positions. We first consider the case when the investor does not have access the activism technology. $\mathcal{A}$ solves the following problem:

$$
\max _{c_{i}}\left\{-\frac{c_{i}^{2}}{2}+c_{i}+(1-\gamma) \mathbf{1}_{s c_{i}>c_{s h o r t}}\left(s c_{i}-c_{\text {short }}\right)\right\}
$$

First, suppose $s=0$, implying that $\mathcal{A}$ does not have an incentive to disclose short positions. In this case, $\mathcal{A}$ chooses $c_{i}$ that solves:

$$
\max _{c_{i}}\left\{-\frac{c_{i}^{2}}{2}+c_{i}\right\}
$$

The first order condition leads to $c_{i}^{*}(\alpha=0, s=0)=1$ and $V\left(c_{i}^{*}(\alpha=0, s=0)\right)=\frac{1}{2}$.

Next, suppose $s>0$ is sufficiently high to justify the disclosure of short position (to be verified). In this case, $\mathcal{A}$ chooses $c_{i}$ that solves:

$$
\max _{c_{i}}\left\{-\frac{c_{i}^{2}}{2}+c_{i}+(1-\gamma)\left(s c_{i}-c_{\text {short }}\right)\right\}
$$

The first order condition leads to $c_{i}^{*}(\alpha=0, s>0)=1+(1-\gamma) s$ and $V\left(c_{i}^{*}(\alpha=0, s>0)\right)=$ $\frac{(1+(1-\gamma) s)^{2}}{2}-(1-\gamma) c_{\text {short }}$. For the disclosure of short position to be optimal at this level of information acquisition, we need to impose the following restriction on the parameters:

$$
c_{\text {short }}<s(1+(1-\gamma) s)
$$

Proposition 1. Suppose condition (B.4) holds and $\mathcal{A}$ does not have access to activism technology. If

$$
c_{\text {short }}>s\left(1+\frac{(1-\gamma) s}{2}\right)
$$


$c_{i}^{*}(\alpha=0)=1, V\left(c_{i}^{*}(\alpha=0)=\frac{1}{2}\right.$, and $\mathcal{A}$ does not disclose his short position. Otherwise $c_{i}^{*}(\alpha=0)=1+(1-\gamma) s, V\left(c_{i}^{*}(\alpha=0)\right)=\frac{(1+(1-\gamma) s)^{2}}{2}-(1-\gamma) c_{\text {short}}$, and $\mathcal{A}$ discloses his short position.

Proof. Follows from comparing $V\left(c_{i}^{*}(\alpha=0, s=0)\right)$ and $V\left(c_{i}^{*}(\alpha=0, s>0)\right)$.

Note that if condition (B.4) holds, $\mathcal{A}$ generates positive profits when he discloses his short position and acquires the corresponding amount of information. If condition (B.5) holds as well, $\mathcal{A}$ prefers to invest less in information acquisition and to not disclose the position. We next show that the access to activism technology can strengthen $\mathcal{A}$ 's incentive to publicly disclose short positions.

Suppose $\mathcal{A}$ has access the activism technology. $\mathcal{A}$ solves the following problem:

$$
\max _{c_{i}}\left\{-\frac{c_{i}^{2}}{2}+c_{i}+\gamma \alpha c_{i}+(1-\gamma) \mathbf{1}_{s c_{i}>c_{\text {short }}}\left(s c_{i}-c_{\text {short }}\right)\right\} .
$$

If $s=0, \mathcal{A}$ does not have an incentive to disclose short positions. In this case, $\mathcal{A}$ chooses $c_{i}$ that solves:

$$
\max _{c_{i}}\left\{-\frac{c_{i}^{2}}{2}+c_{i}+\gamma \alpha c_{i}\right\}
$$

The first order condition leads to $c_{i}^{*}(\alpha>0, s=0)=(1+\gamma \alpha)$ and $V\left(c_{i}^{*}(\alpha>0, s=0)\right)=$ $\frac{(1+\gamma \alpha)^{2}}{2}$. Note that higher $\alpha$ strengthens $\mathcal{A}$ 's incentive to acquire information.

Next, suppose $s>0$ is sufficiently high to justify the disclosure of short position (to be verified). In this case, $\mathcal{A}$ chooses $c_{i}$ that solves:

$$
\max _{c_{i}}\left\{-\frac{c_{i}^{2}}{2}+c_{i}+\gamma \alpha c_{i}+(1-\gamma)\left(s c_{i}-c_{\text {short }}\right)\right\}
$$

The first order condition leads to $c_{i}^{*}(\alpha>0, s>0)=(1+\gamma \alpha+(1-\gamma) s)$ and $V\left(c_{i}^{*}(\alpha>\right.$ $0, s>0))=\frac{(1+\gamma \alpha+(1-\gamma) s)^{2}}{2}-(1-\gamma) c_{\text {short }}$. For the disclosure of short position to be optimal at this level of information acquisition, we need to impose the following restriction on the 
parameters:

$$
c_{\text {short }}<s(1+\gamma \alpha+(1-\gamma) s) \text {. }
$$

Note that if condition (B.9) holds, condition (B.4) holds too. This is because higher $\alpha$ strengthens $\mathcal{A}$ 's incentive to acquire information.

Proposition 2. Suppose condition (B.9) holds. If

$$
c_{\text {short }}>s\left(1+\gamma \alpha+\frac{(1-\gamma) s}{2}\right)
$$

$c_{i}^{*}(\alpha>0)=(1+\gamma \alpha), V\left(c_{i}^{*}(\alpha>0)=\frac{(1+\gamma \alpha)^{2}}{2}\right.$, and $\mathcal{A}$ does not disclose his short position. Otherwise $c_{i}^{*}(\alpha>0)=(1+\gamma \alpha+(1-\gamma) s), V\left(c_{i}^{*}(\alpha=>0)\right)=\frac{(1+\gamma \alpha+(1-\gamma) s)^{2}}{2}-(1-\gamma) c_{\text {short }}$, and $\mathcal{A}$ discloses his short position.

Proof. Follows from comparing $V\left(c_{i}^{*}(\alpha>0, s=0)\right)$ and $V\left(c_{i}^{*}(\alpha>0, s>0)\right)$.

Proposition 3. An investor with activism skills $(\alpha>0)$ is more likely to voluntarily disclose short position than an investor without activism skills $(\alpha=0)$.

Proof. Follows from the right-hand-side of condition (B.10) being an increasing function of $\alpha$.

The main implication of Proposition 3 is that the access to activism technology leads to larger expected benefits from the disclosure of a short position. This happens because the access to activism technology creates is an additional incentive to acquire information: An activist investor can profit not only by trading the stock, but also by taking an action that enhance firm value. Thus, our framework shows that it's possible to have a market in which non-activist short seller prefer to not disclose their short positions whereas activist investors prefer to disclose their short positions. 